\title{
"I DID NOT ALTER THE SITE WHERE THAT TEMPLE STOOD”: THOUGHTS ON ESARHADDON'S REBUILDING OF THE AŠŠUR TEMPLE
}

\author{
Jamie Novotny (The University of Pennsylvania)
}

It is well known that Esarhaddon went to great lengths to repair the damage his father Sennacherib had done in Babylon in the year 689 BCE, when he captured and destroyed that city. Esarhaddon's official inscriptions and other royal propaganda were carefully crafted and worded to present the destruction of Babylon and its subsequent rebuilding as products of the god Marduk's desires and decisions. ${ }^{1}$ Those sources removed all human agency for the actual destruction of Babylon. Therefore, history was presented through the lens of divine abandonment and reconciliation and, thus, Sennacherib and Esarhaddon were merely the chief human agents in Marduk's plans for his city and its inhabitants. In addition, these same texts give the impression that Esarhaddon was extremely cautious when undertaking construction work at Babylon and careful not to alienate or anger Marduk further. The king appears not to have left anything to chance, especially with regard to the interpretation of celestial omens and while carrying out the rebuilding of Esagil and its ziggurat (Etemenanki). To some extent, Esarhaddon may have attributed his father's murder to the destruction of Babylon and its temples. Along this same line, one wonders if Esarhaddon felt that Sennacherib had also offended the god Aššur and that his father paid for that offense with his life. Is there any evidence for this latter suggestion? This paper will investigate that very question and conclude that

I would like to thank the National Endowment for the Humanities for funding the Royal Inscriptions of the Neo-Assyrian Period (RINAP) Project. I would also like to express my gratitude to Professor Grant Frame (director of the RINAP Project), Dr. Mikko Luukko, and Dr. Greta Van Buylaere for reviewing this manuscript. Their time and care are greatly appreciated. Any errors or omissions are solely the responsibility of the author.

The term "Babylon Inscription" here always refers to texts of Esarhaddon composed for Babylon and "Episode(s)" (followed by a number) always refers to episode number(s) assigned to passage(s) by R. Borger in his 1956 Die Inschriften Asarhaddons Königs von Assyriens (Graz: Archiv für Orientforschung, 1956), 10-29 \$11. The translations generally follow those published in A. K. Grayson and J. Novotny, The Royal Inscriptions of Sennacherib, King of Assyria (704-681 BC), RINAP 3/1-2 (Winona Lake, IN: Eisenbrauns, 2012 and 2014) and E. Leichty, The Royal Inscriptions of Esarhaddon, King of Assyria (680-669 BC), Royal Inscriptions of the Neo-Assyrian Period 4 (Winona Lake, IN: Eisenbrauns, 2011).

1. In particular, the Babylon Inscriptions, the Ašsur-Babylon Inscriptions, and the so-called Sin of Sargon text. For the "Sin of Sargon" text, see in particular A. Livingstone, Court Poetry and Literary Miscellanea, SAA 3 (Helsinki: Helsinki University Press, 1989), 77-79 no. 33; H. Tadmor, B. Landsberger, and S. Parpola, "The Sin of Sargon and Sennacherib's Last Will," SAAB 3/1 (1989) 3-51; and E. Frahm, Einleitung in die Sanherib-Inschriften, AfO Beiheft 26 (Vienna: Institut für Orientalistik der Universität Wien, 1997), 227-29 T 186. This text's date of composition, its purpose, and the interpretation of its damaged contents (especially 1l. 17'-19') are still a matter of debate; see, e.g., n. 46 below. With regard to when it was written, most scholars now believe that the "Sin of Sargon" text was composed during the reign of Esarhaddon. In addition, note that K 4743 + Sm 1081 - a fragment from the lower part of a clay tablet that bears a copy of an inscription that was to be written on stone slabs in the Aššur temple at Aššur-contains a composition that is reminiscent of the so-called Sin of Sargon text; Frahm (Sanherib, 229) suggests that that text may have also been written during the reign of Esarhaddon. 
there is some evidence that early in his reign Esarhaddon may have felt that his father had angered the god Aššur by making alterations to his temple at Aššur.

Before examining the issue at hand, let us first look at the textual evidence for Esarhaddon's rebuilding of the Aššur temple at Aššur.

\section{General Overview of the Textual Evidence}

Of the many construction projects undertaken by Esarhaddon, work on the Aššur temple at Aššur appears to have been one of the most important. From the available evidence, the two other most important projects were the construction of a new wing of the armory at Nineveh and the reconstruction of Babylon, especially Marduk's temple and ziggurat (Esagil and Etemenanki). Some details of this project at Aššur are known from six official inscriptions written on clay cylinders, prisms, tablets, and stone tablets. These texts were composed at the beginning of his reign (680-679 BCE) and during his last years as king (ca. 672-670 BCE). ${ }^{2}$ The inscriptions record or mention various stages of building, including: (1) receiving approval for the project through haruspicy; (2) razing the existing temple; (3) making bricks; (4) laying the foundations; (5) building the superstructure; (6) roofing the temple; (7) hanging doors in gateways; (8) sumptuously decorating the temple; (9) placing the god Aššur on his dais; and (10) celebrating the completion of the project. Each account provides slightly different information. What was included or excluded in a given report depended on the date of composition, the object upon which the inscription was written, and the intended destination of the inscription. Since the descriptions are included in inscriptions composed in the name of the king, texts more concerned with royal ideology than historical reality, the reports likely provide idealized descriptions of the rebuilding of the Aššur temple, with the wording carefully chosen to bolster Esarhaddon's image. For example, the accounts that were written in the king's first regnal year (680) describe the project as having already been completed, despite the fact that the actual construction on the temple had yet to take place. ${ }^{3}$ In addition, Esarhaddon regularly called himself bānû bit Aššur "the one who (re)constructed the temple of the god Aššur"; on at least one occasion he referred to himself as mušaklil simātēšu "the one who completed its ornaments."

What physical proof do we have of Esarhaddon having worked on the Aššur temple? In fact, we have very little as only two stone door sockets can be used as evidence to confirm the king's claims. Because neither were found in situ and because the texts themselves do not name the gates for which they were intended, it is not known in which gates these door sockets would have been placed. ${ }^{5}$ Based on the king's titulary in these texts, it is certain that these objects were inscribed after IV-22-671 (Esarhaddon's tenth regnal year). The dating is clear from the use of

2. Leichty, Royal Inscriptions of Esarhaddon, 109 no. 48 1l. 96b-100, 124-128 no. 57 iii 16-viii 3, 131 no. 58 iii 8 -v 6, 133 no. 59 i 19 -ii 12, 136 no. 60 1l. 17'b-33'a, and 153 no. 76 obv. 1-17. Although K 7862 iv 6'-12' (ibid., 101 no. 45) mentions Ehursaggalkurkurra, that passage is not part of the building report. Moreover, K 7862 does not provide any information about the rebuilding of Aššur's temple.

3. See Leichty, Royal Inscriptions of Esarhaddon, 131 no. 58 (Aššur B) iv 5-v 6, and 133 no. 59 (Aššur B) ii 2-12.

4. The epithet bānûu bit Aššur appears in texts from Aššur, Kalhuu, Nineveh, Nippur, Tarbișu, Uruk, and Zinçirli. Those inscriptions were written on clay cylinders, prisms, tablets, stone amulets, beads, stone blocks, human-headed bull and lion colossi, stone slabs, and a stele. See Leichty, Royal Inscriptions of Esarhaddon, nos. 1, 10, 12, 43, 48, 64, 65, 66, 74, 75, 77, 78, 79, 84, 85, 86, 93, 98, 128, 129, 133, 134, 135, and 136. The earliest certain use of that epithet appears in a text dated to VI-26-677 (Esarhaddon's 4th regnal year); see ibid., 56 no. 10 l. 3 . The epithet mušaklil simātěšu is known only from a stele from Zinçirli, an inscription composed after IV-22-671 (Esarhaddon's 10th regnal year); see ibid., 184 no. 98 rev. 2.

5. Leichty, Royal Inscriptions of Esarhaddon, 145-46 nos. 68-69. BM 115703 (1922-8-12, 173; Ass 5286; Leichty, Royal Inscriptions of Esarhaddon, no. 68) was clearly part of the temple. It was discovered in the Aššur temple, north of Temple A (iB4III). Although EŞ 7137 (Ass 14271; ibid., no. 69) was found in the city area, its association with the Aššur temple is based on the opening dedication to the god Aššur (l. 1). Unlike the door sockets of Sennacherib from Aššur's temple, Esarhaddon's door sockets do not name the gate in which they were placed. Cf. Grayson and Novotny, Royal Inscriptions of Sennacherib 2:261-62 no. 190-91. Based on the shape and size of the objects, as well as the lineation of the inscriptions, it is likely that BM 115703 and EŞ 7137 were placed in different gates of the temple. 
the title šar šarrāni Mușur Paturisi u Küsi "king of the kings of (Lower) Egypt, Upper Egypt, and Kush.”' Based on their provenance, several stone blocks may have also come from part of the Aššur temple built by Esarhaddon; the poorly preserved texts inscribed on them, however, provide no direct evidence for them being part of this temple. ${ }^{7}$ Moreover, the provenances of some of the inscribed stone and clay objects (see fig. 1) strongly indicate that they were deposited or displayed in Aššur's temple.

Finally, the wording of several building reports of his immediate successor on the Assyrian throne, Aššurbanipal, suggests that Esarhaddon worked on the Aššrur temple. Aššrurbanipal states in his inscriptions that he merely "completed" (ušaklil // agmur) the Ǎšur temple, rather than having built and completed (arșip ušaklil) it. ${ }^{8}$ Those inscriptions also suggest that Esarhaddon had not completed the project before he died in the year 669, as his own texts claim.

\section{The Sources and Their Building Reports: General Overview}

In 1969, G. van Driel noted that W. Andrae and his team do not describe the archaeological evidence for construction on the Aššur temple after the time of Sennacherib since the remains of that temple were meager. Therefore, what Esarhaddon actually did cannot be determined accurately. Thus, we more or less only have textual evidence for this king's rebuilding of Aššur's temple. ${ }^{9}$ So then, what did Esarhaddon claim to have done? Let us briefly review the known sources and their building reports.

\section{Leichty, Royal Inscriptions of Esarhaddon, 129-34 nos. 58-59=A Ǎšur B}

Two clay cylinders, a cylinder fragment, and three fragmentarily preserved clay prisms are inscribed with a text recording the rebuilding of the Aššur temple. Most of these pieces were discovered in the vicinity of the Aššur temple, in area iD4V (the southern part of the forecourt). ${ }^{10}$ Although none of the cylinders and prisms inscribed with Aššur B were dated, it is likely that Aššur B was one of the earliest official texts composed during Esarhaddon's reign. Based on the dates of the known copies of Aššur A, which come from the first half of his second regnal year (679), and the fact that Esarhaddon's accession year (681) was at most twenty-two days long in Assyria, Aššur B probably dates to his first regnal year (680). ${ }^{11}$ The early date of composition is suggested by the brevity of the inscription, especially the shortness of its building report. The text was likely first written on small, solid cylinders and then on prisms. The Aššur B text that was written on cylinders is nearly identical to the Aššur B text that was inscribed on prisms, apart from orthographic variants and two variants in the prologue: The prism copies add one additional epithet for both Esarhaddon's father Sennacherib and grandfather Sargon II. ${ }^{12}$

6. Leichty, Royal Inscriptions of Esarhaddon, 145 no. 68 1l. 3-4a, and 146 no. 69 11. 5-7.

7. Leichty, Royal Inscriptions of Esarhaddon, 142-44 nos. 65-67. Ass 17290 (no. 65) was discovered in area iA3III and Ass 16891 (no. 66) and Ass 16150 (no. 67) were found in area iC3II. One or more of these may be the stone blocks mentioned on W. Andrae, Das wiedererstandene Assur, 2nd ed. (Munich: Beck, 1977), 230.

8. See R. Borger, Beiträge zum Inschriftenwerk Assurbanipals: Die Prismenklassen $A, B, C=K, D, E, F, G, H$, J und T sowie andere Inschriften (Wiesbaden: Harrassowitz, 1996), 138 Prism T i 14-15 // Prism C i 16-17, p. 176 Prism E Stück 6 1. 3, and p. 268 IIT 1. 28.

9. G. van Driel, The Cult of Aššrur, Studia Semitica Neerlandica 13 (Assen: Van Gorcum, 1969), 29. W. Andrae (Das wiedererstandene Assur, 230) states that limestone foundation blocks found in the area of the cult rooms attest to Esarhaddon working on the Aššur temple.

10. Leichty, Royal Inscriptions of Esarhaddon, 129-34 nos. 58-59. VA 7517 (Ass 3696; = no. 58 ex. 1) was discovered in area kA4III, about $5 \mathrm{~m}$ from the embankment wall; VA 7510 (Ass 1969; = no. 58 ex. 2) was found in area gE5i, at the western end of a large opening; VA 7514 (Ass $946 ;=$ no. 58 ex. 3) came from area iD4V, east of the Prothysenpflaster; VA 7511 (Ass 943; no. 59 ex. 1) originated from area iD4V; VA 15471 (Ass 10430; = no. 59 ex. 2) was discovered in the city area; and VA 8412 (Ass 18343; = no. 59 ex. 3) was found in the northern part of area iD4V.

11. For details, see most recently J. Novotny, "Esarhaddon's Babylon Inscriptions Revisited: New Proposed Chronological Sequence, New Proposed Dates of Composition, and a New Trans-Atlantic Join," JCS forthcoming, n. 3.

12. The prism version of Aššur B adds e pišs șalam Aššur u ilāni rabûti "the one who fashioned image(s) of (the god) Aššur and the great 
Šamšì-Adad I

Shalmaneser I

Sargon II, Sennacherib

Legend:

$1=$ Text no. 60

$2=$ Text no. 65

$3=$ Text nos. $66,67,57.7$

$4=$ Text no. 68

$5=$ Text no. 57.9

$6=$ Text no. 57.3

$7=$ Text nos. 58.3, 59.1, 59.3

$8=$ Text nos. 57.2, 57.5

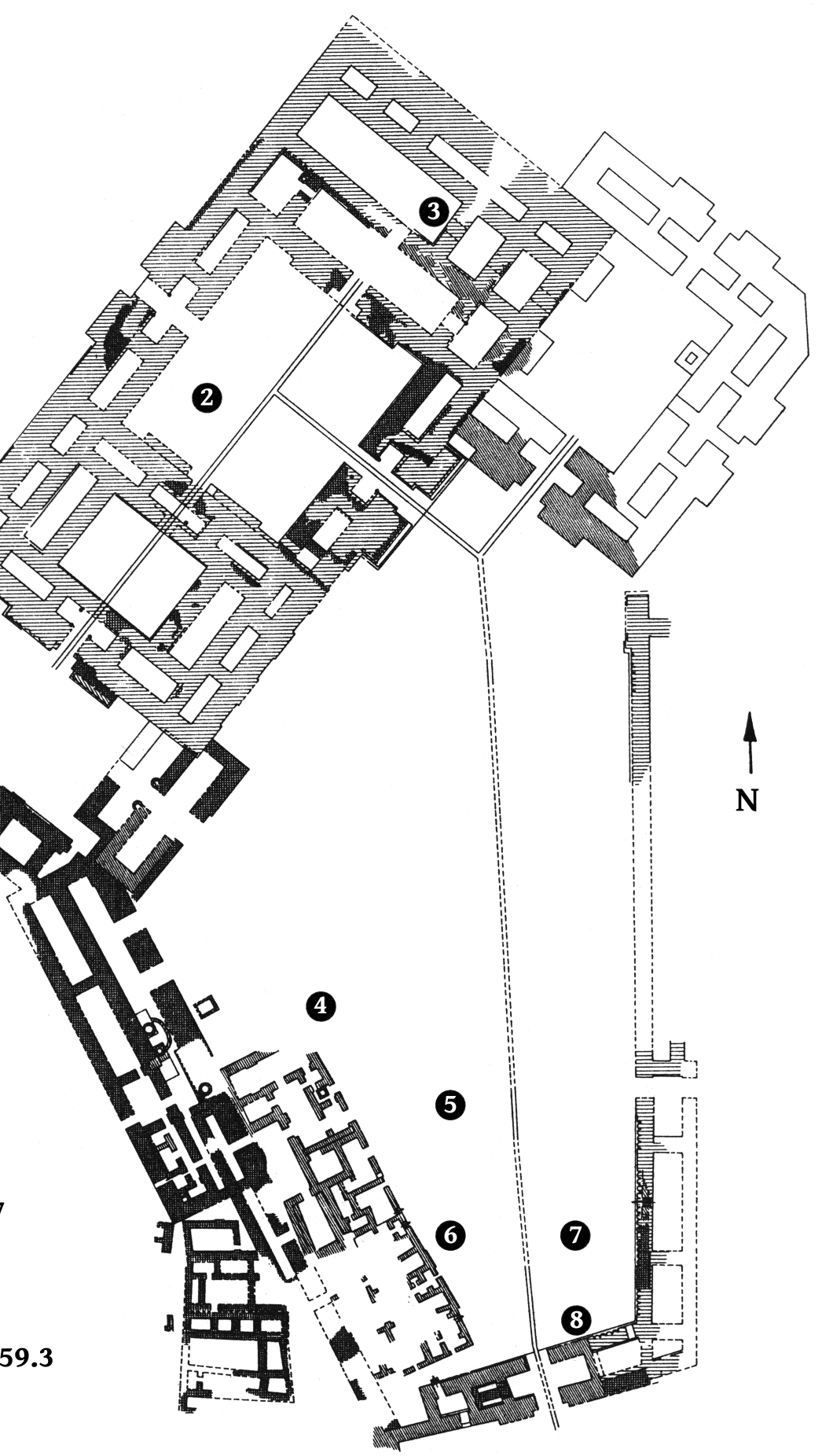

Fig. 1. Plan of the Aššur temple showing the find spots of some of his inscriptions. Adapted from Haller, Heiligtümer, pl. 5. 
Aššur B’s building report is short and vague. It records that: (1) the Aššur temple, which had last been built by Šalmaneser I 586 years earlier, had fallen into ruin; (2) Esarhaddon did not alter the location of the temple; (3) the king laid the foundations on gold, silver, precious stones, aromatics, and the resin of the hašüru-tree, thereby, making a secure base for the brick superstructure; and (4) the temple was built and completed. ${ }^{13}$ Unlike the marginally later Aššur A text, Aššur B's building report lacks most of the details about the project, in particular those of the later stages of building. Nevertheless, in true Assyrian style, the work is described as having already been completed, although little, if any, actual work apart from the demolishing of the old temple and the fashioning of bricks had likely taken place.

\section{Leichty, Royal Inscriptions of Esarhaddon, 119-29 no. 57 = Ařšur A}

Seven fragmentarily preserved eight-sided clay prisms, a fragment of a clay tablet, and a fragment of a stone tablet are inscribed with a text recording in detail the rebuilding of the Aššr temple. Several of these pieces were discovered in the vicinity of Aššur's temple, the southern part of the forecourt (areas iC4IV, iC4V, and iD5I). ${ }^{14}$ Two of the pieces preserve dates: One prism (ex. 1) was inscribed on IV-19-679 and another (ex. 3) was inscribed on III-[...]-679. Based on the length of the inscription and the amount of detail included in the building report, it is highly probable that Aššur A is later in date than Aššur B; the latter was likely composed in Esarhaddon's first regnal year (680) and the former early in his second regnal year (679). Because the two dated fragments of Aššur A were written anywhere between twelve and forty-two days apart (based on the information provided by their date lines), it is not known how long Esarhaddon had his scribes write the Aššur A text on clay and stone objects. Therefore, Aššur A should be regarded as a snapshot of what the Assyrian king intended to undertake on the Aššur temple at the beginning of his second year as king. For all we know, Aššur A could have been written on objects for a short time (not more than a few months) or for a long period of time (six months to a year or more than a year). ${ }^{15}$

The building report of Aššur A provides information about various stages of the construction, from the demolition of the former temple and the making of bricks in preparation for the rebuilding to the return of the statue of Aššur during three days of celebration. Since this inscription was written just over a year after Esarhaddon became king, it is doubtful that much of the construction itself had actually taken place, apart from the removal of the previous brick superstructure and the making of bricks. This is not a surprise since it was expected of the Assyrian king to boast about any given building achievement as if that project had already been completed. This is likely because official inscriptions often have more to do with royal ideology than with historical reality. Thus, in the case of building reports, the information included likely presents the intentions of the king, rather than what he had actually achieved. ${ }^{16}$ Nevertheless, even if we have to take what is reported in these sources with a grain of salt,

gods" as an epithet of Sennacherib and mušte " $\hat{u}$ ašrăt Ǎ̌šur u Mullissi "the one who is assiduous towards the shrines of the god Aššur and the goddess Mullissu" as an epithet of Sargon II. Compare Leichty, Royal Inscriptions of Esarhaddon, 130-31 no. 58 ii 10-iii 7 to 133 no. 59 i $15-18$.

13. Leichty, Royal Inscriptions of Esarhaddon, 131 no. 58 iii 8-v 6 and 133 no. 59 i 19-ii 12.

14. Leichty, Royal Inscriptions of Esarhaddon, 119-29 no. 57. Part of VA $8411+$ VA 10130 (+) UM 32-22-5 (Ass 12260; = no. 57 ex. 1) was discovered in area fA10V, on the brick pavement, and another part was purchased by E. A. Speiser in 1931-32 in "Assyria"; VA 7513 (Ass 1783; $=$ no. 57 ex. 2) was found in area iD5I, in the rubble, under the west wall of the Parthian ruins of the southeast gate; VA 7504 (Ass 986; = no. 57 ex. 3) was discovered in area iC4V, north of the altar base; VA 8428 (Ass 8814; = no. 57 ex. 4) originated from area dA6II, east of the Red House; Ass 18231a-b (VA -; = no. 57 ex. 5) was found in area iD5I, in the pavement of the post-Assyrian gate; VA 5935 (Ass 16123; = no. 57 ex. 7) was discovered in the northwest section of area iC3II; VA Ass 4719 (Ass 19525; = no. 57 ex. 8) came from the area of the embankment wall; and VA 7507 (Ass 1532; = no. 57 ex. 9) was found in area iC4IV, north of the Prothysenpflaster. The provenance of VAT $9642+$ VAT 11095 + VAT 11682 (= no. 57 ex. 6) was not recorded.

15. The issue is described in more detail in J. Novotny, "Esarhaddon's Babylon Inscriptions."

16. To use a modern comparison, think of architectural models and concept drawings created by architects/architectural firms to sell their designs to clients and to advertise/show off those buildings as they are being constructed. 
these building accounts provide essential information to our understanding of the history of Assyria and, in the case of Aššur A, the history of the Aššur temple. So then, what does Esarhaddon claim to have done in this text?

Before diving into the description of the building itself, Esarhaddon gives a selective history of the temple, noting that it was built by Ušpia, Erišum I, Šamšī-Adad I, and Šalmaneser I. Aššur A states that 126 years had passed between Erišum I's and Šamši-Adad I's rebuilding, that 434 years had passed between Šamšì-Adad's and Šalmaneser I's rebuilding, and that 580 years had passed between Šalmaneser's and Esarhaddon's own rebuilding. ${ }^{17}$ The king claims to have been anxious about rebuilding the temple and had his diviners confirm that he should undertake the project through haruspicy. The gods Šamaš and Adad are reported to have given their approval, which they had written out on the liver inspected by the king's haruspices. Once he had divine approval, Esarhaddon had the superstructure of the dilapidated temple removed, various liquids mixed into the mortar of bricks, and bricks made in wooden molds. ${ }^{18}$ The king claims to have had bricks made for an entire year, which could be true or could just be a literary topos echoing Enūma eliš Tablet VI 1. 60: šat-tu iš-ta-at li-bit-ta-šú il-tab-nu "they made its bricks for one year. ${ }^{19}$ During that time, Esarhaddon reports that he personally made bricks and carried a basket on his head. According to the text, the ritual was to inspire the workers..$^{20}$ At the appropriate time-during a favorable month, on an auspicious day-the limestone foundations were laid on gold, silver, (precious) stones, antimony, aromatics, and various types of liquids ( $p \bar{u} r u$-oil, fine oil, honey, ghee, beer, and wine). Aššur A also states that the king made foundation documents and placed them in the temple. ${ }^{21}$ The text inserts at this point a statement reporting that Esarhaddon himself mixed oil, fine oil, püru-oil, honey, ghee, and cedar resin into the mortar of the bricks and that he then carried the very first brick (the libittu mahritu) on his neck to the building site. The bricks mentioned here are probably the same as the ones he claims to have made earlier in the text. ${ }^{22}$ According to the text, Esarhaddon accomplished all of the aforementioned work in the first year of the project.

17. It is certain that Esarhaddon's workmen had discovered inscriptions of Šalmaneser I while removing the dilapidating structure of the Aššrur temple since the history of the temple was inspired by the list of previous builders in those texts. Šalmaneser I states that 159 years passed between Erišum I's and Šamšì-Adad I's rebuilding and that 580 years passed between Šamšī-Adad's and Šalmaneser I's own rebuilding; see A. K. Grayson, Assyrian Rulers of the Third and Second Millennia BC (to 1115 BC), RIMA 1 (Toronto: University of Toronto Press, 1987), 185 A.0.77.1 11. 112-128 and 189 A.0.77.2 11. 5-13a. Note in particular that the distance between Šamšĩ-Adad I and Šalmaneser I in the Šalmaneser texts and the distance between Šalmaneser I and Esarhaddon in Aššur A are identical: 580 years. For studies on time-spans ("Distanzangaben") in Assyrian texts, see, for example, C. Eder, "Assyrische Distanzangaben und die absolute Chronologie Vorderasiens," AoF 31 (2004) 191-236; R. Pruzsinszky, "Zum Verständnis der assyrischen Distanzangaben: Beiträge zur assyrischen Chronologie," SAAB 14 (2002-5) 23-31; and R. Pruzsinszky, Mesopotamian Chronology of the 2nd Millennium B.C.: An Introduction to the Textual Evidence and Related Chronological Issues, Österrichische Akademie der Wissenschaften Denkschriften der Gesamtakademie 56 (Vienna: Österrichische Akademie der Wissenschaften, 2009), 133-50. For further information on the names of rulers mentioned in late Neo-Assyrian building reports, see the appendix.

18. Esarhaddon states that people conquered by him provided the labor for the project. By the time Aššr A was composed, Esarhaddon would have conducted few military campaigns so it is more likely that the conquered foreigners living in Aššur or brought to that city would have been captured and brought to Assyria during the reign of his father Sennacherib.

19. W. G. Lambert, Babylonian Creation Myths, MC 16 (Winona Lake, IN: Eisenbrauns, 2013), 112. M. Cogan ("Omens and Ideology in the Babylon Inscription of Esarhaddon," in History, Historiography and Interpretation: Studies in Biblical and Cuneiform Literatures, ed. H. Tadmor and M. Weinfeld [Jerusalem: Magnes, 1983], 85) and B. N. Porter (Images, Power, and Politics: Figurative Aspects of Esarhaddon's Babylonian Policy [681-669 BC], Memoirs of the American Philosophical Society 208 [Philadelphia: American Philosophical Society, 1993], 172) think this is just a literary topos. Esarhaddon also claims to have had bricks made for Esagil for an entire year; see, e.g., Leichty, Royal Inscriptions of Esarhaddon, 246 no. 116 rev. $13 \mathrm{~b}$.

20. Three steles of Aššurbanipal and one stele of Šamaš-šuma-ukin likely depict similar events during which those two kings carried bricks. See Frame, Babylonia 689-627 B.C.: A Political History, PIHANS 69 (Leiden: Nederlands Institut voor het Nabije Oosten, 1992), cover (BM 90864), 352 fig. 2 (BM 90865), and 353 fig. 3 (BM 90866); and J. E. Reade and C. B. F. Walker, "Some Neo-Assyrian Royal Inscriptions," AfO 28 (1981-82) 119 no. 4 fig. 8 (BM 22533). For further details on the objects and their inscriptions, see G. Frame, Rulers of Babylonia from the Second Dynasty of Isin to the End of Assyrian Domination (1157-612 BC), Royal Inscriptions of Mesopotamia, Babylonian Periods 2 (Toronto: University of Toronto Press, 1995), 199-202 no. B.6.32.2, 217-19 B.6.32.14, and 252-53 B.6.33.3.

21. The materials are different from those mentioned in Aššr B. That text states that the king laid the foundations on gold, silver, precious stones, aromatics, and the resin of the hašüru-tree. Compare Leichty, Royal Inscriptions of Esarhaddon, 126 no. 57 v 3-13a to 131 no. 58 iv 9-14 and 133 no. 59 ii $5-8$.

22. The precise relationship between Esarhaddon carrying the basket (kudurru) on his head and the first brick (the libittu mahritu) on his neck is unclear. It is not known with certainty if these two passages refer to the same event or to different ceremonies. For details on the first 
In the second year of construction, which just happened to coincide with the composition of Aššr A, Esarhaddon records that he built the superstructure of the temple from its foundations to its parapets and restored the shrines, daises, and cult platforms; the tops of the walls are said to have been raised to the sky. The king mentions that he roofed the temple with beams of cedar and cypress and hung gold-banded cypress doors in gateways; the wood is said to have come from Mount Sirāra and Mount Lebanon in the Levant.

As is to be expected with regard to a project in its early stages of construction, little is said about the decoration of the temple’s interior. Aššr A claims that Ehursaggula ("House, Big Mountain") was made to glisten like the stars of the firmament and that whatever utensils were required for the temple were made. ${ }^{23}$ Statues of the god Aššr and the other gods of the temple, including Ninurta and Nusku, are reported to have been returned to their proper places; Aššur himself would have resided on the Dais of Destinies. To commemorate the completion of the temple, Esarhaddon planned elaborate ceremonies, including a three-day celebration. Numerous offerings were to be made at that time.

\section{Leichty, Royal Inscriptions of Esarhaddon, 103-9 no. $48=$ Aššur-Babylon A}

Two large, single-column clay tablets and a small fragment of a third tablet preserve archival copies or drafts of the first part of inscriptions that were to be inscribed on a stele and possibly other stone (or clay) objects. The three pieces are presumed to have come from Nineveh. ${ }^{24}$ Aššur-Babylon A was written late in Esarhaddon's reign, after IV-22-671 (his tenth regnal year) since his control over Egypt and Kush is referred to in the title šar šarrāni Dilmun Maganna Meluhh ha "king of the kings of Dilmun, Magan, (and) Meluhha.." 25 Although the main focus of the lengthy building report (1l. 61b-108) is concerned with the restoration of the damaged statues of the god Marduk and his entourage, reference is made to work on the Aššrur temple. The text claims that Esarhaddon laid the foundations of Ehursaggalkurkurra, Esagil, and Babylon on gold, silver, aromatics, and several liquids during a favorable month, on an auspicious day, and, thereby, ensured that the brick superstructure could be built on top of those foundations. ${ }^{26}$ Only the very early stages of the work are recorded, and in a conflated manner. The materials upon which

brick ritual, see C. Ambos, "Building Rituals from the First Millennium BC: The Evidence from the Ritual Texts," in From the Foundations to the Crenellations: Essays on Temple Building in the Ancient Near East and Hebrew Bible, ed. M. J. Boda and J. Novotny, AOAT 366 (Münster: Ugarit-Verlag, 2010), 227-28; C. Ambos, Mesopotamische Baurituale aus dem 1. Jahrtausend v. Chr. (Dresden: ISLET Verlag, 2004), 77-78; and J. Novotny, "Temple Building in Assyria: Evidence from Royal Inscriptions," in From the Foundations, 119-20. For information on royal participation, see R. S. Ellis, Foundation Deposits in Ancient Mesopotamia, YNER 2 (New Haven: Yale University Press, 1968), $20-31$.

23. According to some copies of the Götteradressbuch (1. 145), Ehursaggula was the bìt šuhùru of the temple; see, for example, George, Babylonian Topographical Texts, OLA 40 (Leuven: Peeters, 1992), 176 no. $20 \$ 4$. This may be Room q (van Driel, Cult of Aššur, 22). Inscriptions of Aššurbanipal state that he made the god Aššur enter Ehursaggula and sit upon his dais; see Borger, Beiträge zum Inschriftenwerk Assurbanipals, 138 Prism C i 21-22 // Prism T i 19-20, and 176 Prism E Stück 6 1l. 6-7. Prism E explicitly states that the image of Ǎšur was placed in Ehursaggula, which was the cella (atmanu) of his divinity. The corresponding passages in Prisms C and T (as well as Prisms G and Kh) are ambiguous. Based on Prism E, Ehursaggula would have to be Rooms o+p, the main cult room of the temple; see van Driel, Cult of Aššur, 22. At present, it is not certain to which actual room or rooms of the Aššur temple Aššur A v 39-42a refer. In Aššur-Babylon E 11. 23'b-25' (Leichty, Royal Inscriptions of Esarhaddon, 136 no. 60), Esarhaddon records that he sumptuously decorated the cella (atmanu) and antecella (bit papāhi), which may have been Rooms o+p and Room m respectively.

24. Leichty, Royal Inscriptions of Esarhaddon, 103-9 no. 48. K $2801+$ K $3053+$ DT 252 (ex. 1) and K $221+$ K 2669 (ex. 2) more or less duplicate one another. The final lines of K $221+$, however, deviate significantly from those of K $2801+$; those lines are not sufficiently preserved to be able to assess their contents accurately. Compare ibid., 109 no. 48 ll. 103-108 (= K 2801+ rev. 51-56) to ex. 2 ll. 103-112 (= K 221+ rev. $46-56$ [which are followed by a lacuna]). K 18057 (ex. 3) is not sufficiently preserved to be certain that it is actually a duplicate of K $2801+$ and K 221+; only parts of 11. 71-72 are extant.

It is clear from the subscript (ibid., 109 ll. 109-110) that the text written on K 2801+ (ex. 1) was intended to be inscribed on the left side of a stele (asumittu) or was copied from that object. The subscript also states that the contents of the tablet were only the first part of the text. No subscript is preserved on K 221+ (ex. 2) so it is not certain what type of object that inscription was intended for. It may have also been written on a stele or on another stone (or clay) object.

25. Leichty, Royal Inscriptions of Esarhaddon, 105 11. 28b-29a.

26. Leichty, Royal Inscriptions of Esarhaddon, 109 no. 48 11. 98b-100. In lieu of $a b$-[̌̌i-im-ma] "I bu[ilt and]" read $x x$ (no translation pos- 
the foundations were placed differ from those mentioned in the building reports of Aššur A and Aššur B. AššurBabylon A states that the foundations were set on gold, silver, aromatics, honey, ghee, wine, kurunnu-wine, and another material; Aššur B records that the foundations were placed on gold, silver, precious stones, aromatics, and resin of the ḩašūru-tree; and Aššur A claims that Esarhaddon had the foundations placed on gold, silver, stones, antimony, aromatics, püru-oil, fine oil, honey, ghee, beer, and wine. ${ }^{27}$

\section{Leichty, Royal Inscriptions of Esarhaddon, 134-37 no. $60=$ Aššur-Babylon E}

A large, but damaged alabaster tablet discovered in the vicinity of the Aššur temple (area hC4I) and a small fragment of a clay tablet presumed to have come from Nineveh (Kuyunjik) have an inscription of Esarhaddon describing work at Aššur and Babylon written on them. ${ }^{28}$ Aššur-Babylon E was written late in Esarhaddon's reign, after IV-22-671 (his tenth regnal year) since the defeat of the Egyptian pharaoh Taharqa and the conquest of Egypt are mentioned.$^{29}$ The text is probably slightly later in date than Aššur-Babylon A. The building report, as the modern designation indicates, describes work at Aššur and Babylon, including the refurbishing of the statues of Marduk and his entourage in a workshop at Ǎšur. The description of Esarhaddon's work on the Aššur temple in Ašsur-Babylon $\mathrm{E}$ is the latest known report of the project and it mostly concerns itself with the interior decoration of certain rooms and gateways. ${ }^{30}$

The opening section of the seventeen-line account of building at Aššur summarizes the demolition of the old temple and the construction of the new temple. Esarhaddon records that he: (1) demolished the temple, which had been built previously by Šalmaneser I, down to its foundation pit; (2) relaid the foundations with blocks of limestone; (3) rebuilt the brick superstructure; (4) roofed the temple with cedar beams; and (5) hung metalbanded doors in gateways. Afterwards, Aššur-Babylon E describes in detail some of the decoration of Aššurs cella and antecella, as well as some of the gateways in their vicinity; unfortunately, none of the ornate objects mentioned survive today. Esarhaddon boasts that he decorated the cella (atmanu) with gold; fashioned statues of lahmu-monsters and kurïbu-genii; and rebuilt the Dais of Destinies upon which the image of Aššur stood. AššurBabylon E records that the apotropaic figures were made from red șâriru-gold and that the dais was constructed from 180 talents of ešmarû-silver and had depicted on it images of Esarhaddon and the heir designate of Assyria, Ašsurbanipal. ${ }^{31}$ Esarhaddon states that he lavishly decorated the walls of the antecella (bit papāhi) with gold and

sible). The new reading is based on a collation by the author from a photograph of K 2801+. See also the copy in B. Meissner and P. Rost, "Die Bauinschriften Asarhaddons," in Beiträge zur Assyriologie und semitischen Sprachwissenschaft 3, ed. F. Delitzsch and P. Haupt (Leipzig: Hinrichs, 1898), 297. Moreover, the ša (written šá) before Ehursaggalkurkurra in 1.98 must be connected with a possessive suffix, the -šun on uššu (written $\mathrm{US}_{8}-\check{s} \breve{u}-u n$ ) and, therefore, the reconstruction of a clause final verb without a closing, corresponding suffix for ša is highly unlikely. The signs $x x$ may have been the name of another material upon which the foundations were placed. Because the laying of the foundation would have been done during a favorable month, on an auspicious day, the (first) main verb of the clause must have been nad $\hat{u}$, despite the fact that it is erroneously written $a d-d u-u$, instead of the expected $a d-d i$. The scribe may have been influenced by its proximity to the preposition/ conjunction èma "wherever, whenever."

27. Respectively Leichty, Royal Inscriptions of Esarhaddon, 109 no. $481.100,131$ no. 58 iv 9-14 and 133 no. 59 ii 5-8, and 126 no. 57 v 5-11. The mention of kurunnu-wine in connection with the foundations also appears in ibid., 246 no. 116 rev. 22.

28. Leichty, Royal Inscriptions of Esarhaddon, 134-37 no. 60. EŞ 6262 (Ass 3916; ex. 1) is the alabaster tablet from Aššur and K 18096 (ex. 2 ) is a clay tablet presumably from Nineveh. K 18096 is not sufficient preserved for us to be certain that it actually contains a duplicate of the text inscribed on EŞ 6262. The passage concerning the Aššur temple, assuming it had one, is not preserved on K 18096.

29. Leichty, Royal Inscriptions of Esarhaddon, 135 no. 60 ll. 8'b-9'.

30. Leichty, Royal Inscriptions of Esarhaddon, 136 no. 6 1l. 17'b-33'a.

31. The cella is Rooms o+p of the temple; see van Driel, Cult of Ǎšsur, 22. It is unclear whether the statues of the lahmus and kuribus were made entirely from metal or were merely decorated with metal. Based on Esarhaddon's description of the previous Dais of Destinies, which he states was made from baked bricks and (a plating of) zahalu-silver, it appears that the dais was constructed entirely from (bricks cast of) ešmarû-silver. This interpretation can be confirmed by the statement, assuming that it is correct, that 180 talents of ešmarûu were used to build Aššur's dais. Following M. A. Powell's calculations ("Masse und Gewichte," RLA 7/7-8 [1990] 510-11), this would have been ca. 5,400 kg $(=11,880 \mathrm{lb})$ of metal; a talent is estimated to have been ca. $30 \mathrm{~kg}$. While demolishing the existing dais, Esarhaddon appears to have removed 
made gold statues of creatures of the apsî to be stationed in it. ${ }^{32}$ The building report of Aššur-Babylon E also records that Esarhaddon had apotropaic figures made and placed in three prominent gateways (see figs. 2-4): bronze bison (kusarikku) in the "Gate of the Path of the Enlil-Stars" (bāb ḩarrān šüt Enlil) and deluge monsters (abūbu) in the "Royal Gate" (bāb šarrūti) and the "Kamsū-Igìgū Gate" (bāb kamsū Igīgī). ${ }^{33}$

\section{Leichty, Royal Inscriptions of Esarhaddon, 152-53 no. $76=$ Ass $21506 e$}

A small, unbaked clay tablet contains an approximately thirty-four-line text recording work on the Aššr temple in a literary style similar to a poem. ${ }^{34}$ The object is known only from an excavation photograph of its obverse (Ass ph 6554). ${ }^{35}$ The present location of Ass $21506 \mathrm{e}$ is not known, as are the contents of its reverse, which was not photographed or copied. The contents of the obverse provide details of the early, prebuilding stages of the project: the gathering of workmen, making sacrifices, mixing liquids into the mortar of bricks, and making of bricks. Although the contents more or less mirror the account of Ǎšur A, the Ass 21506e text provides a few variant details. First, the god Aššur personally orders Esarhaddon to undertake the rebuilding and decoration of the temple; the means of communication is not recorded. Second, Esarhaddon is said to have made offerings before having liquids mixed into the mud for the bricks. ${ }^{36}$ Third, the list of liquids mixed into the bricks includes milk (sizbu) and resin of the ḩašūru-tree and excludes püru-oil and cedar resin (dām erēni) ${ }^{37}$ Fourth, and last, the attendees at one of the brick carrying rituals are mentioned: important people (kabtūtu), unimportant people (sehrütu), and a daughter of the king. Because the reverse was not photographed or copied, it is not known what other details about the rebuilding of the Aššur temple the Ass $21506 e$ text would have described. Moreover, there are no clues in the text itself to be able to determine its date of composition accurately.

the metal plating that his father had placed around its brickwork. BM 91157, a fragment of bronze in the British Museum (London), may be part of that plating. For details and an edition of the inscription written on it, see Grayson and Novotny, Royal Inscriptions of Sennacherib 2:19 and 263-64 no. 193. Moreover, probably inspired by work of his father at Aššur, Aššurbanipal had Marduk’s dais in Esagil constructed from bricks made from fifty talents of $z$ ahalu- - -silver; that is ca. $1,500 \mathrm{~kg}(=3,300 \mathrm{lb})$ of metal.

32. The antecella is probably Room $m$ of the temple; see van Driel, Cult of Aššur, 22.

33. There is no scholarly consensus on the location of these gateways. Compare, for example, figs. 2-4. The "Gate of the Path of the Enlil-Stars" either (1) provided access from Room q (possibly the temple’s bit šuh ü $r u$ ) to a large courtyard (the courtyard of the "Ostanbau"), (2) provided access between Room q and Aššur's cella, or (3) provided access between Room m and the main courtyard (Haupthof). The "Royal Gate" may have been (1) the entranceway between the cella (Rooms $\mathrm{o}+\mathrm{p}$ ) and Room q, (2) the entranceway leading from Room q to the courtyard of the "Ostanbau," or (3) the entranceway between the cella (Rooms o+p) and the antecella (Room m). The "Kamsū-Igigun Gate" may have been (1) the outer gate of the southwest wall of the "Ostanbau" (which led to the forecourt), (2) the inner gate of the southwest wall of the "Ostanbau," or (3) the inner gate of the south wall of the forecourt. See, for example, J. Börker-Klähn, "Der bit hilāni im bìt šahūuri des Assur-Tempels," ZA 70 (1980) 260-62 (with fig. 2) gates a, a', and c; Frahm, Sanherib, 172; and H. Galter, "Die Bautätigkeit Sanheribs am Aššurtempel," Or 53 (1984) 440-41. Frahm's interpretation is tentatively followed here. For further details about the gates (with references to previous studies), see Grayson and Novotny, Royal Inscriptions of Sennacherib, 2:18-19. Note that Sennacherib also ornately decorated the "Gate of the Path of the Enlil-Stars" with metal statues of four bull-shaped son-of-Šamaš figures and a fish-man, a bronze carp-man, a lion-man, and a scorpion-man; see Grayson and Novotny, Royal Inscriptions of Sennacherib, 2:234 no. 166 ll. 17b-22a, and 278 no. 209 obv. 3'-10'. For a study of the apotropaic figures, see M. Huxley, "The Gates and Guardians in Sennacherib’s Addition to the Temple of Assur," Iraq 62 (2000) 109-37.

34. Leichty, Royal Inscriptions of Esarhaddon, 152-53 no. 76.

35. Ass $21506 \mathrm{e}$ was discovered in area iC6III, in the destruction fill of a house, $0.6 \mathrm{~m}$ below the surface, $7 \mathrm{~m}$ from the eastern wall, and $0.5 \mathrm{~m}$ from the northern wall. The tablet was found with in a group of about ninety-two complete and fragmentary clay tablets (Group A), including other royal hymns, literary texts (including Tablet II of the Anzû Myth), and lexical lists (including har $=$ hubullu). For further details on the find spot and on the N3 archive, see O. Pedersén, Archives and Libraries in the City of Assur: A Survey of the Material from the German Excavations 2, Studia Semitica Upsaliensia 8 (Uppsala: Almquist and Wiksell, 1986), 34-41.

36. Compare Leichty, Royal Inscriptions of Esarhaddon, 246 no. 116 rev. 21, where Esarhaddon had offerings made to the great gods (of Esagil?) and to the brick god Kulla.

37. Compare Leichty, Royal Inscriptions of Esarhaddon, 153 no. 76 obv. 15-16a to 126 no. $126 \mathrm{v} 18-22$. The liquids are mixed into kalakku in the former text, but they are mixed into šallaru in the latter text. 
Šamšī-Adad I

Shalmaneser I

$\mathbb{N}$ Sargon II, Sennacherib

\section{Legend:}

Rooms o+p = Aššur's cella

Room $q$ = šuhūru-house?

Gate $1=b \bar{a} b$ šarrūti?

Gate $2=b \bar{a} b$ ḩarrān šūt Enlil?

Gate $3=b \bar{a} b$ burūme $\vec{e}$ ?

Gate 4 = bāb nēreb Igīgì?

Gate 5 = bāb kamsī Igīgì?

Gate $\mathbf{6}=\mathbf{b} \bar{a} b$ hișib māti?

Gate $7=b \bar{a} b$ ereqqi?

Gate 8 = bāb parak šìmāte?

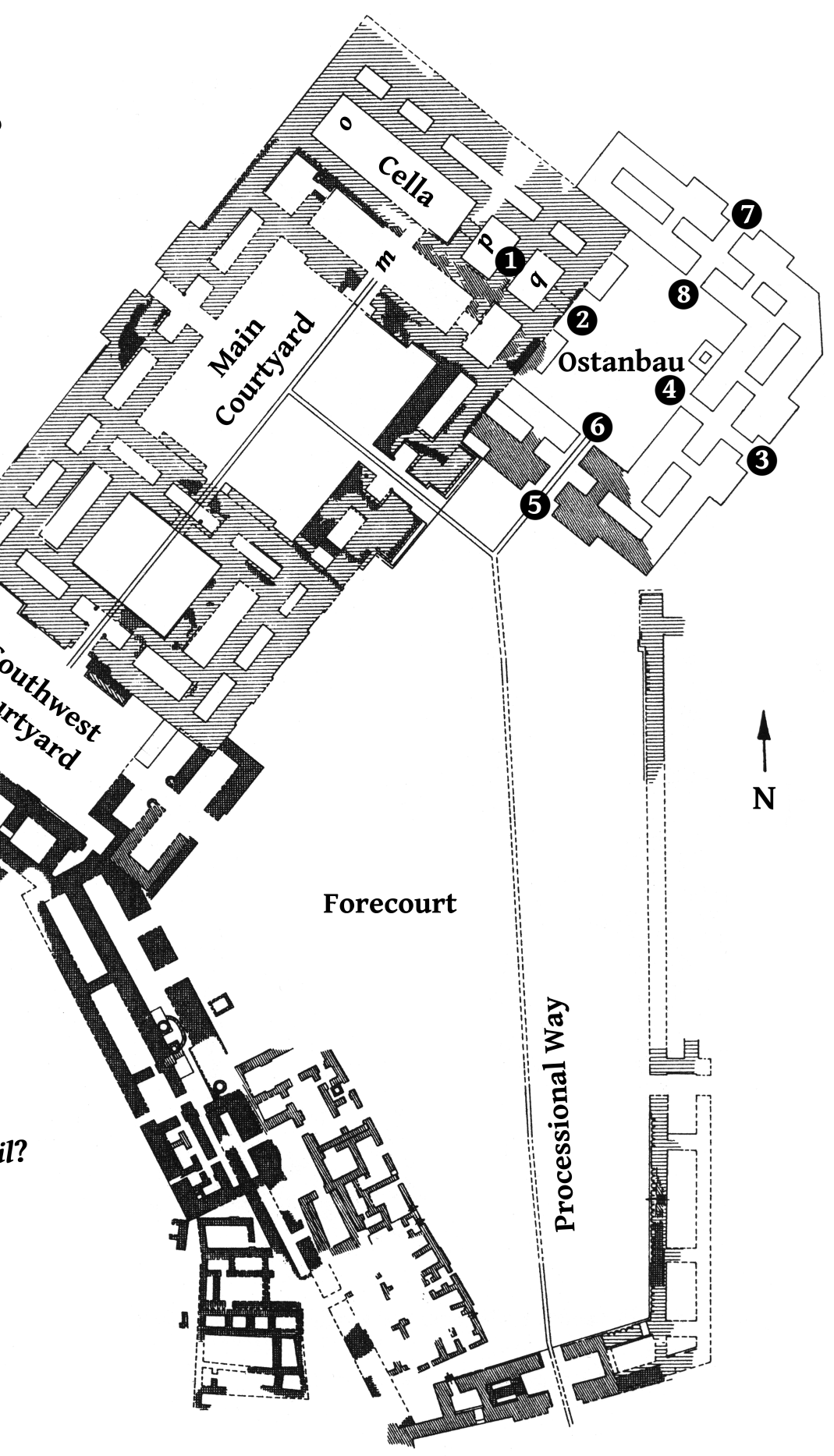

Fig. 2. Plan of the Aššur temple showing Frahm's proposed identifications of Sennacherib's new gates. Adapted from Haller, Heiligtümer, pl. 5. 


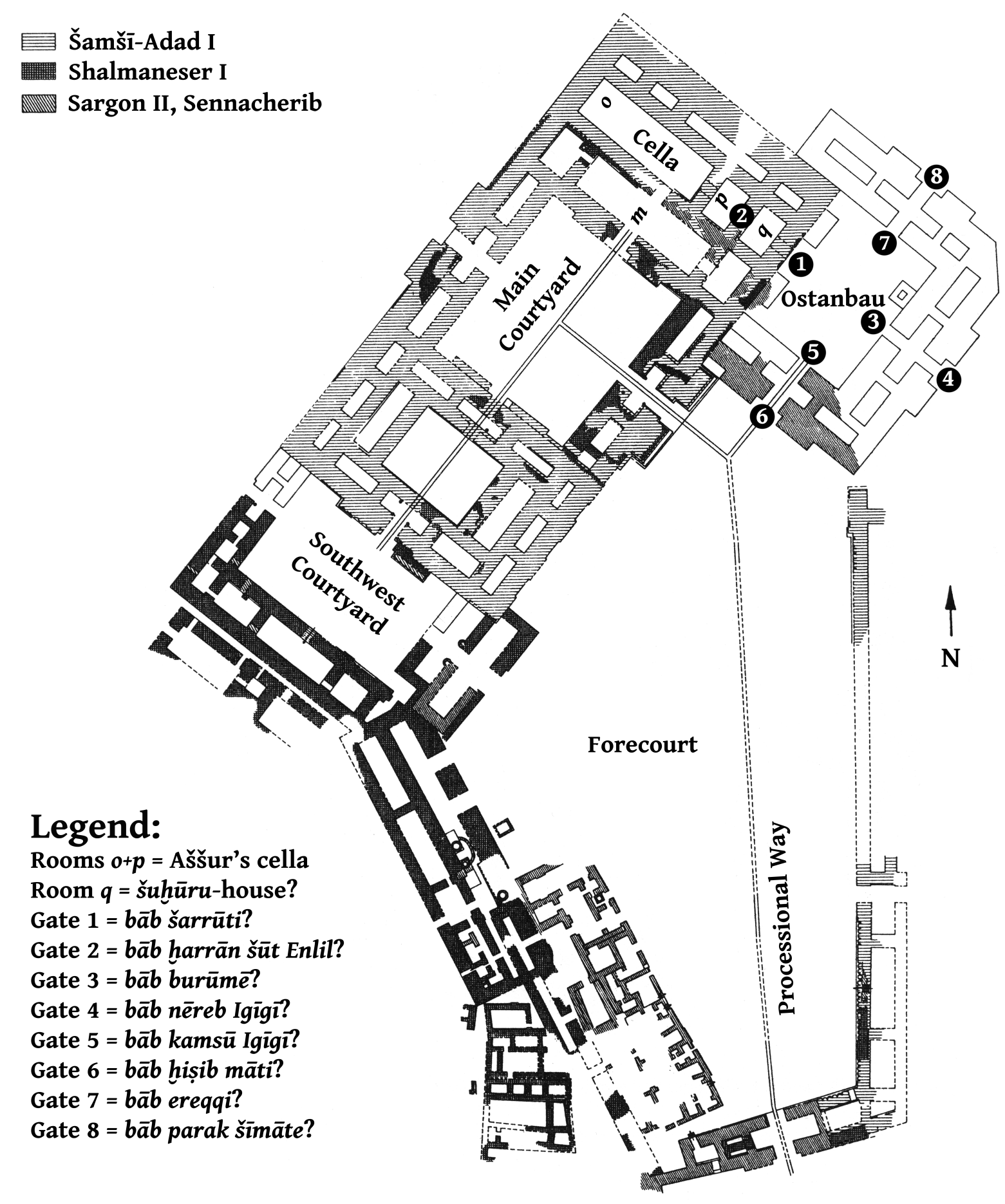

Fig. 3. Plan of the Aššur temple showing Börker-Khähn's proposed identifications of Sennacherib's new gates. Adapted from Haller, Heiligtümer, pl. 5. 


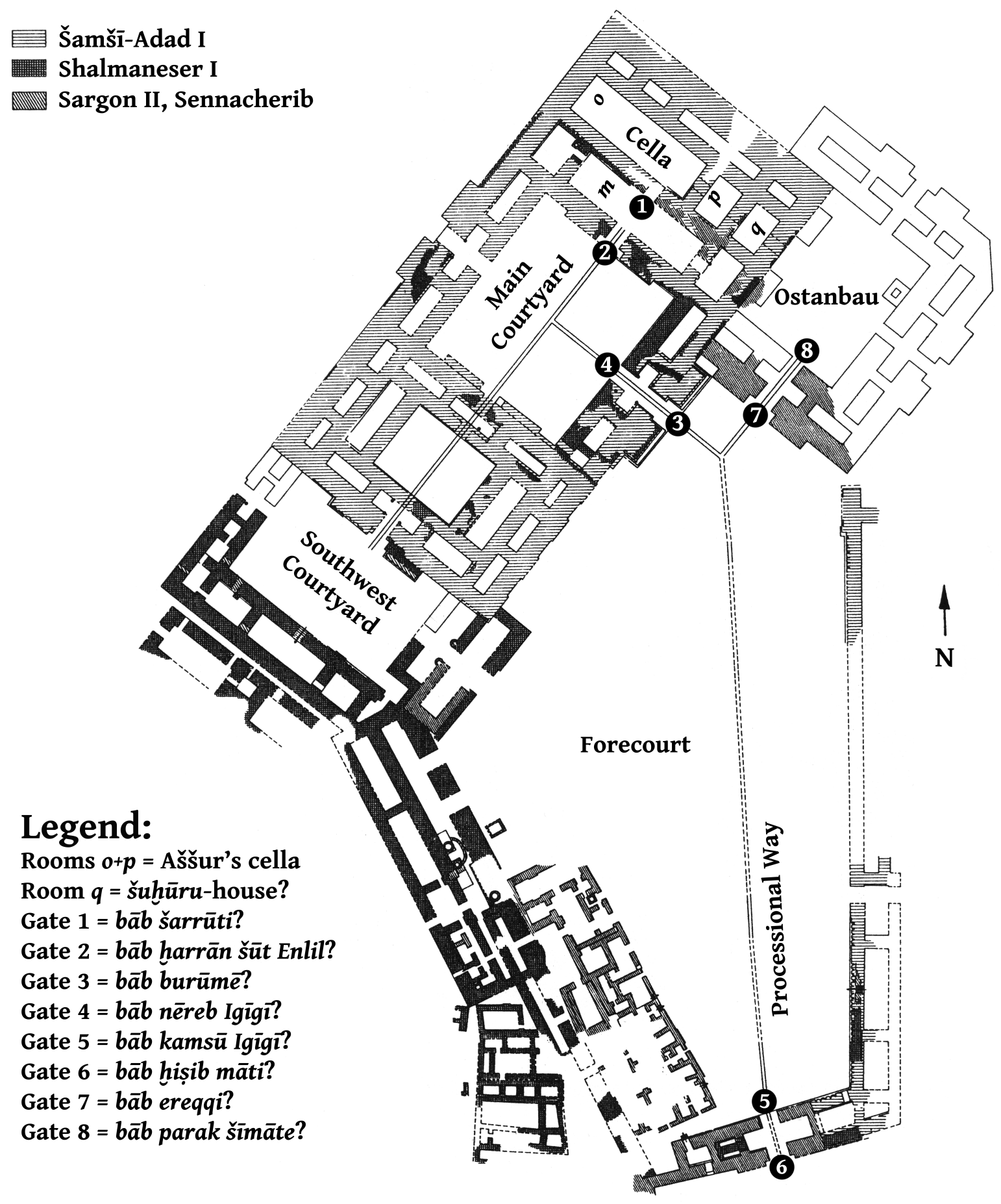

Fig. 4. Plan of the Aššur temple showing Galters's proposed identifications of Sennacherib's new gates. Adapted from Haller, Heiligtümer, pl. 5. 


\section{bītu šuātu ašar maškanšu ul ušanni, "I did not alter the site where that temple stood"}

There is little doubt that Esarhaddon regarded the rebuilding of Aššr temple as one of his most important building projects. Work appears to have started sometime during his first regnal year (680) and clay foundation documents (cylinders and prisms) were inscribed with texts commemorating this work, with the intent that some of them would be placed in the structure of the temple. The building reports of the two earliest texts describing this project, Aššur B and Aššur A, present different information, especially for the earliest stages of construction. One notable difference is that Aššur B records that Esarhaddon did not change the plan of the temple, whereas this detail is not included in Aššur A. Specifically, the former states bìtu šuātu ašar maškanšu ul ušanni, "I did not alter the site where that temple stood." ${ }^{38}$ This statement and similar claims made in his Babylon Inscriptions are curious since building reports of Esarhaddon's predecessors do not make such claims. ${ }^{39}$ In fact, Esarhaddon's own father Sennacherib reports that he made alterations and additions to Aššur's temple and changed the location of the akitu-house, moving the festival house from inside Aššur to outside the city's western wall. ${ }^{40}$ Based on texts and archaeological evidence, Assyrian rulers prior to Esarhaddon do not appear to have had an issue with altering the plan or position of temples; note also that Aššurbanipal changed the plan of at least one temple (Ehulhul at Harrān). ${ }^{41}$ What were the immediate historical circumstances that brought this apparent change of attitude and prompted him to conduct building projects in exact accordance with the former plans of the buildings he was restoring?

In the case of Babylon, this is not difficult to figure out since Sennacherib had destroyed the city and its temples in late 689. With the aid of his advisors, Esarhaddon took every means possible to ensure that Marduk, who revealed that he had become reconciled with Babylon through auspicious celestial omens, was not offended by any action the Assyrian king, and de facto ruler of Babylon, did while restoring Babylon and its temples to their former glory. A three-part strategy was, at least initially, put in place. First, Esarhaddon distanced himself from his father, the very man responsible for Babylon's destruction, by not stating that he was the son of Sennacherib in texts composed for objects intended for Babylon. ${ }^{42}$ Second, while rebuilding Marduk's temple, Esarhaddon claims not to have deviated, even a little bit, from the existing ground plan. In particular, he explicitly states that he did not diminish Esagil by even a single cubit nor increase it by half a cubit; specifically, the texts record ištêt ammatu ul ašêt mišil ammatu ul utter "I did not add a (single) cubit, nor subtract a half cubit." ${ }^{33}$ The inclusion of such statements in the Babylon Inscriptions shows that Esarhaddon was anxious about righting the wrong done by his father, and rebuilding the temple according to its former ground plan was seen as one means to this end. Even though Sen-

38. Compare Leichty, Royal Inscriptions of Esarhaddon, 131 no. 58 iv 5-17 and 133 no. 59 ii 2-9 to 126 no. 57 v 3-28.

39. For similar statements in Esarhaddon's Babylon Inscriptions, see, for example, Leichty, Royal Inscriptions of Esarhaddon, no. 104 iii 41b-46, 206 no. 105 iv 37b-v 1, 230 no. 113 ll. 25b-26a, and 246 no. 116 rev. 15-19. In addition, Esarhaddon states that he regularly sought out the previous foundations of buildings prior to rebuilding them. See, e.g., ibid., 262 no. 128 1. 16, 265 no. 129 1. 31 , and 272 no. 133 1. 32. For studies on this stage of building, see, for example, Ellis, Foundation Deposits, 12-17; Novotny, From the Foundations, 115-18; and Schaudig, "The Restoration of Temples in the Neo- and Late Babylonian Periods: A Royal Prerogative as the Setting for Political Argument" in From the Foundations, 147-50.

40. See Grayson and Novotny, Royal Inscriptions of Sennacherib 2:240-41 no. 166 1l. 8b-27a and $244-45$ no. 168 11. $22 \mathrm{~b}-36 \mathrm{a}$.

41. For example, the plans of the Aššur, Ištar, and Sîn-Šamaš temples at Aššur changed several times throughout their histories. For the plans of those temples, see W. Andrae, Die jüngeren Ischtar-Tempel in Assur, WVDOG 58 (Leipzig: Hinrichs, 1935), pls. 1, 4, and 6-7; A. Haller, Die Heiligtümer des Gottes Assur und der Sin-Šamaš-Tempel in Assur, WVDOG 67 (Berlin: Gebr. Mann, 1955), 52-73; and P. Werner, Der Sîn-Šamaš-Tempel in Assur, Wissenschaftliche Veröffentlichungen der Deutschen Orient-Gesellschaft 122 (Wiesbaden: Harrassowitz, 2009 ), 16-25. For the textual evidence indicating that Aššurbanipal changed the plan of Ehulhul at Huarrān by enlarging it, see Borger, Beiträge zum Inschriftenwerk Assurbanipals, 142-43 Prism C i 83 // Prism T ii 45-46.

42. See Leichty, Royal Inscriptions of Esarhaddon, 194-95 no. 104 i 1-18a, 203 no. 105 i 1-19, 212 no. 106 i 1-9, 222 no. 109 i 1'-12', 231 no. 114 i 1-6, and 247 no. 117 obv. 1'-4'. During the period 672-669, however, Esarhaddon seems not to have had a problem mentioning that he was the son of Sennacherib; see, for example, ibid., 229 no. $11311.4 \mathrm{~b}-5 \mathrm{a}$.

43. Leichty, Royal Inscriptions of Esarhaddon, 198 no. 104 iii $42 \mathrm{~b}-46$ and 206 no. 105 iv 38-v 1. 
nacherib was Marduk's agent in destroying Babylon, that Assyrian king was not seen as being blameless. ${ }^{44}$ Third, having taken the necessary measures not to offend Babylon's tutelary deity with any of the contents of inscriptions displayed or deposited in Esagil and Babylon, it was important to date the inscribed objects accurately and honestly. Therefore, the date written on clay prisms had to be Esarhaddon's šanat rēššarrüti "accession year" since he never took the hand of the god Marduk during an akitu-festival at Babylon. Esarhaddon could not officially begin counting his regnal years as ruler of Babylon because Marduk was not in a position to confer kingship on Esarhaddon; the coronation ceremony could take place only at Babylon itself. Despite the fact that Esarhaddon's authority over Sumer and Akkad was recognized, the entire duration of his twelve-year reign as king of Assyria was considered as his accession year in Babylon. ${ }^{45}$ In short, Esarhaddon's not deviating even the slightest from the existing plan of Esagil when he was having it rebuilt should be seen as a direct response to his father destroying Marduk's temple, an act that may have been seen as one of the sins for which Sennacherib ultimately paid with his life in late $681{ }^{46}$

If one regards the fact that Esarhaddon did not have a single cubit added or a half cubit subtracted from the plan of Esagil while rebuilding it as a reaction to the deeds of his father a little more than a decade earlier, then perhaps Esarhaddon's decision to not change the plan of the Aššur temple at Aššur may have also been a direct response to a perceived sin of Sennacherib, this time against the god Aššr. If that was the case, what exactly did Sennacherib do and whom did he offend? Also, what did Esarhaddon do in response apart from not making any changes to the existing Aššur temple? To answer these questions, let us first look at Sennacherib’s work on Aššur's temple.

At least eleven inscriptions of Sennacherib record work on the Aššur temple. These are written on two horizontal stone cylinders, several stone blocks, numerous bricks, and a clay tablet. ${ }^{47}$ Most, if not all of these, are presumed to have been composed during the post-689 period, an eight-year period during which Sennacherib inaugurated several religious reforms. Nothing is known about him working on the Ǎšur temple during his first sixteen years as king (704-689). After sacking and destroying Babylon in late 689 (Sennacherib’s sixteenth regnal year), Sennacherib remodeled and rebuilt the central sanctuary of the Aššur temple in an attempt to make it more like the Esagil complex at Babylon. ${ }^{48}$ Sennacherib had a new, multiroom complex (the so-called Ostanbau) added onto

44. For Sennacherib's own account of the destruction, see Grayson and Novotny, Royal Inscriptions of Sennacherib, 2:312-13 no. 223 11. 43b-54a. In Esarhaddon's Babylon Inscriptions, all human agency is removed from the destruction. See, e.g., Leichty, Royal Inscriptions of Esarhaddon, 196 no. 104 i 34-ii 2a, 203-4 no. 105 i 37b-ii 15, 212 no. 106 i 10-ii 3, 236 no. 114 i 19-ii 11, and 244-45 no. 116 obv. 7'-17'.

45. This matter is discussed by the author in detail in J. Novotny, "Esarhaddon's Babylon Inscriptions," in press.

46. According to A. M. Weaver ("The 'Sin of Sargon' and Esarhaddon's Reconception of Sennacherib: A Study of Divine Will, Human Politics and Royal Ideology," Iraq 66 [2004] 61-66), the "Sin of Sargon" text may indirectly refer to the destruction of Esagil. Moreover, she proposes that Sennacherib should be recast as Sargon II and Esarhaddon should be recast as Sennacherib in that text. Weaver based her speculative interpretation entirely on S. Parpola's edition ("Sennacherib's Last Will," 10-24), without firsthand consultation of the Akkadian original. Parpola notes in his commentary that some of his restorations (including those in $11.17^{\prime}-19^{\prime}$, a crucial passage in the text) "must be regarded as tentative only"; see, for example, E. Frahm's critical notes to 11. 17'-19' (Sanherib, 228). Weaver's proposal, given a closer look at the text itself, seems unlikely; compare, for example, the statement of B. Landsberger ("Sennacherib's Last Will," 33) about this composition's central message: "My father (Sargon) was punished for a neglect of Aššrur, I (Sennacherib) have been punished for a neglect of Marduk"; and the comments of E. Frahm (Sanherib, 228). Therefore, there is no need to assume that the roles of Sargon II and Sennacherib are played by Sennacherib and Esarhaddon respectfully. In any event, Weaver's interpretation of the "Sin of Sargon" has no impact on this paper. Sennacherib's perceived sin against the god Aššur, that is, the alteration of that god's temple, does not appear to have been included in this badly damaged piece of royal propaganda and, therefore, by the time the "Sin of Sargon" text had been composed that transgression had been forgotten or deliberately overlooked as Esarhaddon's rebuilding of the Aššur temple was in the advanced stages of completion; remember that reference to Esarhaddon not altering that temple's site is omitted already in the Aššur A inscription, a text written on clay prisms during the first half of Esarhaddon's second regnal year (679).

47. Grayson and Novotny, Royal Inscriptions of Sennacherib, 2:236-41 no. 166, 246-47 no. 169, 266-68 nos. 190-91, 269-75 nos. 193-98, and $284-85$ no. 209.

48. The "Ostanbau," the new multiroom complex, may have been loosely modeled on the eastern annex of Esagil, thereby making Aššur's temple more like Marduk's, at least in general terms (a courtyard with four gates). Moreover, this new addition may have even been the Assyrian counterpart of the Babylonian Ubšu-ukkinna (the location of the divine assembly). For details, see A. R. George, "E-SANGIL and E-TEMENANKI, the Archetypal Cult-Centre," in Babylon: Focus mesopotamischer Geschichte, Wiege früher Gelehrsamkeit, Mythos in der Moderne: 2. internationales Colloquium der Deutschen Orient-Gesellschaft, 24.-26. März 1998 in Berlin, ed. J. Renger, CDOG 2 (Saarbrück: Saarbrücker 
the existing structure. A new entrance to the main cult rooms was built. ${ }^{49}$ The king states that his predecessors had disregarded the proper orientation of the entrance to Aššur's cella (Rooms $0+p$ ) so he created a new entrance. The old south-facing entrance was replaced by a new east-facing entrance, which he named the "Royal Gate" (bāb šarrüti). ${ }^{50}$ Along with the changes made to this temple, which the king states were divinely approved through extispicy, Sennacherib also had a new akitu-house constructed outside the western wall of the city.

In connection with the reorientation of the principal entrance to Aššr's cella, Sennacherib rebuilt the bit šsh hūru (possibly Room q) and widened and decorated its gate, which he named the "Gate of the Path of the Enlil-Stars" (bāb ḩarrān šūt Enlil). That ornately decorated gate-which had metal statues of four bull-shaped son-of-Šamaš figures and a fish-man, a bronze carp-man, a lion-man, and a scorpion-man-probably provided the bit šuhüru access to a large courtyard (the courtyard of the "Ostanbau"). ${ }^{51}$ Sennacherib constructed a new paved courtyard, which he called the "Courtyard of the Row of Pedestals for the Igīgū Gods" (kisal sidir manzāz Igīgī).52 Inner and outer gates were placed in the southeast, northeast, and southwest walls; the northwest wall, which formed part of the existing structure of the temple, also had inner and outer gates (the "Royal Gate" and the "Gate of the Path of the Enlil-Stars"). The inner and outer gates in the southeast wall (those facing east, towards the Tigris River) were probably the "Gate of Entrance of the Igīgū Gods" ( $b \bar{a} b$ nèreb Igīgì) and the "Gate of the Firmament" (bāb burūmē); those in the southwest wall (those facing south) were likely the "Gate of the Abundance of the Land" (bāb hissib $m \bar{a} t i)$ and the "Kamsū-Igīgū Gate" (bāb kamsī Igīgì); and those in the northeast wall (those facing north) were probably the "Gate of the Dais of Destinies" (bāb parak šimāte) and the "Gate of the Wagon Star" (bāb ereqqi). ${ }^{53}$ Doors of cedar were hung in these gateways; their door posts rested upon door sockets made from kašurrû-stone (a type of basalt). In the southwest corner of the newly built courtyard, Sennacherib placed a large, elaborately sculpted stone water basin; a well was dug nearby. Sennacherib states that he also had a portable bronze brazier installed in this courtyard.

The forecourt, as indicated by archaeological evidence, was raised and repaved; bricks of his father Sargon II were reused.

Two pieces of metal plating attest to Sennacherib having objects that were plated with bronze in the temple. One of the pieces may have adorned the Dais of Destinies (parak šimāte). In addition to being inscribed, that

Druckerei und Verlag, 1999), 67-86, esp. p. 75 fig. la and pp. 77-79.

49. For information on what remained of the "Ostanbau," see Haller, Heiligtümer, 69-73. The work appears to have been carried out in two stages.

50. Sennacherib's south-facing entrance is oriented to the southwest; the gate is presumed to have been the entrance that led to the antecella (Room m). The east-facing entrance, which Sennacherib named the "Royal Gate," is actually oriented to the southeast and it may have been the entranceway between the cella (Rooms o+p) and Room q (so Frahm, Sanherib, 172) or the entranceway leading from Room q to the courtyard of the "Ostanbau" (Börker-Klähn, "Der bit hilāni," 260-61 [with fig. 2] gate a). According to H. Galter ("Die Bautätigkeit Sanheribs," 440-41), the "Royal Gate" was the entranceway between the cella (Rooms o+p) and the antecella (Room m). For a discussion of the problems with the Akkadian terms used in the Sennacherib inscription that is written on horizontal stone prisms (Grayson and Novotny, Royal Inscriptions of Sennacherib, 2:236-41 no. 166) to indicate the orientation of the gates, along with references to previous literature, see Frahm, Sanherib, 170.

51. So Frahm, Sanherib, 172. However, J. Börker-Klähn ("Der bìt hilāni," 261-62 [with fig. 2] gate a') suggests that the "Gate of the Path of the Enlil-Stars" provided access between Room q and Aššur's cella (Rooms o+p). H. Galter ("Die Bautätigkeit Sanheribs," 440-41) proposes that the gate was between Room $\mathrm{m}$ and the main courtyard (Haupthof). Compare figs. 2-4. For a reconstruction of the ornate gateway created by Sennacherib, see Börker-Klähn, "Der bït hilāni," 273 fig. 4. For a study of the apotropaic figures, see Huxley, "Gates and Guardians," $109-37$.

52. So Börker-Klähn, "Der bīt hilāni," 261-62 [with fig. 2] courtyard z; and Frahm, Sanherib, 172. See figs. 2 and 3.

53. So Frahm, Sanherib, 172. Börker-Klähn, "Der bìt hilāni," 261-62 [fig. 2] gates b, b', c, c', d, and d') proposes more or less the same arrangement, but regards the "Gate of the Firmament," the "Kamsū-Igīgū Gate," and the "Gate of the Wagon Star" as the inner gates, and the "Gate of Entrance of the Igīgu Gods," the "Gate of the Abundance of the Land," and the "Gate of the Dais of Destinies" as the outer gates. H. Galter ("Die Bautätigkeit Sanheribs," 440-41) places the gates around the temple's forecourt (Vorhof). According to Galter, the "Gate of Entrance of the Igīgū Gods" was located between the main courtyard (Haupthof) and Room a; the "Gate of the Firmament" probably gave Room a access to the forecourt; the "Kamsū-Igīgū Gate" and the "Gate of the Abundance of the Land" were located at the very southern end of the forecourt; and the "Gate of the Wagon Star" and the "Gate of the Dais of Destinies" provided access from the forecourt to the courtyard of the "Ostanbau." Compare figs. 2-4. 
bronze plating may have also depicted the Tablet of Destinies, the god Aššur, and Sennacherib. ${ }^{54} \mathrm{~A}$ tablet copy of a dedicatory inscription attests to the king having a kettledrum made for the god Aššur; this text would have been written on the metal plating of the drum. There were presumably other objects made for Assyria's principal deity at this time, but the written and archaeological evidence for this are lacking. It is known from two tablets inscribed during the reign of Aššurbanipal that Sennacherib dedicated Marduk's bed and throne to Aššur after he had them removed from the Esagil temple at Babylon; Sennacherib had dedicatory inscriptions written on the metal plating of those objects..$^{55}$

In sum, Sennacherib appears to have altered the main cult room by changing the orientation of its principal entryway, rebuilt the bit šahūru to accommodate the changes to the temple's plan, built a new multiroom complex (the so-called Ostanbau) southeast of Aššur's cella, and decorated these sections of the temple. The alterations in the temple's plan made it necessary to change the route of the processional way. Although Sennacherib's inscriptions do not state the reasons that the plan of the temple was changed, it is clear from the inscriptions of Esarhaddon and Aššrbanipal that Aššur's temple was made to be more like Marduk's temple at Babylon. This was just part of the process through which the Assyrian god usurped the image, power, and attributes of Babylon's tutelary deity. ${ }^{56}$

These numerous changes may have ruffled more than a few feathers, especially within the Aššr priesthood. When Sennacherib was murdered, some people may have seen that foul deed as divine retribution for the alterations made to Aššrur's temple and cult, in particular for making them more like their counterparts at Babylon. Contention between the Aššr and Babylon priesthoods is referred to in the so-called Sin of Sargon text. Rev. $21^{\prime}-23^{\prime}$ reads:

As for me, after I had made the image of (the god) Aššur my lord, Assyrian scribes kept preventing me from working [on the image of the god Marduk] and (thereby) did not allow me fashion [the image of the god Marduk, the great lord], and (thus) [ended my li]fe. [...]..$^{57}$

Here, the Assyrian king alludes to the problems he faced when trying to restore Marduk's damaged statue. Despite claiming in his official inscriptions that his changes to the Aššur temple were divinely approved, Sennacherib may have faced opposition when he proposed alterations to the temple's plan and cult. Few members of the Aššur priesthood would have been pleased to know that their sacred space was to be overhauled to make it more like Babylon's principal temple. Therefore, when Esarhaddon became king, some members of the Aššr priesthood may have made it known to their new king that they felt that Sennacherib was murdered for his sins against the god Aššur.

So, how would Esarhaddon have reacted to that news? On some level, at least during his first regnal year (680), he must have felt that Sennacherib had offended Aššur by making changes to his temple and cult. If he did not feel

54. Grayson and Novotny, Royal Inscriptions of Sennacherib, 2:269-70 text no. 193. As suggested by E. Frahm (Sanherib, 221), one or both of the inscriptions written on clay tablet K $6177+$ K 8869 may have also been written on the metal plating of the Dais of Destinies. If BM 91157 proves to be from the plating of Aššur's dais, then the drafts (or archival copies) of the texts written on K $6177+\mathrm{K} 8869$ may have been inscribed elsewhere on that same piece of bronze. Esarhaddon (Leichty, Royal Inscriptions of Esarhaddon, 136 no. 60 ll. 26'-29'a) records that he constructed the Dais of Destinies entirely from ešmarû-metal; he states that its outer facing depicted both him and his son Ǎšurbanipal. If Esarhaddon did have Aššur's dais completely rebuilt with metal, then he would have had his father's bronze plating, which may have included the fragment now in the British Museum (BM 91157), removed before dismantling its brick structure. Before doing so, he probably had the inscriptions written on the earlier plating copied onto a clay tablet and archived; K $6177+$ K 8869 may have been that tablet. The bronze plating itself, assuming BM 91157 actually was part of the plating of the Dais of Destinies, was not destroyed by Esarhaddon's craftsmen. Of course, this interpretation of the meager evidence must remain conjectural.

55. K 8664 (Grayson and Novotny, Royal Inscriptions of Sennacherib, 2:223-25 no. 161) and K 2411 (ibid., 225-28 no. 162). Other cult objects taken from Esagil in 689 were probably dedicated to the god Aššur.

56. Late in his reign (ca. 638), Aššurbanipal refers to Ešarra as tamšil bit Enlil ša šamê "a replica of the temple of the Enlil of the heavens (=Marduk)"; see Borger, Beiträge zum Inschriftenwerk Assurbanipals, 268 IIT 11. 29b-30a.

57. Livingstone, Court Poetry, 79 no. 33; and Tadmor, Landsberger, and Parpola, "Sennacherib's Last Will," 14-15. 
that way, the reference in Aššur B to him not altering the plan of the temple does not have any immediate historical context, especially since there is no evidence from earlier and later royal inscriptions and from the archaeological record that Assyrian kings had any problem with changing the plan or location of a temple. Esarhaddon's decision to rebuild the Aššur temple without making any changes may have been rooted in an event that had taken place just prior to him ascending the throne. Sennacherib's alteration of the main cult rooms and the route of the processional way, as well as the addition of a new multiroom complex, may have been that event. Members of the A ššrur priesthood likely told Esarhaddon that his father had offended Aššur by carrying out these changes and, thereby, paid for it with his life. The Marduk priesthood presumably told him a similar story about his father's destruction of Babylon and Esagil. Thinking that his father had angered Aššur and Marduk by changing and destroying their temples respectively, Esarhaddon took it upon himself to right the wrong of his father by faithfully following the existing plans of those structures when he had them rebuilt. Interestingly, and probably to the dismay of the A ššrur priesthood, Esarhaddon did not undo the changes of his father. The new multiroom complex (the "Ostanbau") was not dismantled, as it is clear from Aššur-Babylon E that Esarhaddon had several of its gateways decorated with apotropaic figures ${ }^{58}$ Despite the pressure he may have felt to undo his father's alterations, the Assyrian king may have been very reluctant to have undertaken that work, especially since his advisors had deeply engrained in him the idea that deviating from the existing plan of a temple would offend its divine owner. Even if Esarhaddon felt that Sennacherib had sinned against the god Aššur by changing the plan of his temple, it appears that he was reluctant to anger Aššur by making the same mistake as his father. Therefore, he refused to change the temple back to the way it was prior to his father working on it. Because this interpretation is conjectural, this need not have been the case. For example, perhaps changing the plan of the temple back to the pre-Sennacherib plan may have upset supporters/followers of his father, including members of the Aššur priesthood, who felt that the creation of the new multiroom complex was what the god Aššr had wanted.

In sum, Esarhaddon may have thought that his father Sennacherib offended the god Aššur by altering that deity's cult and temple. Members of the Aššur priesthood may have told him this because they were upset that the temple and cult of their god too closely resembled those of Esagil. Having been advised that altering a temple's plan was a sin punishable by death, as clearly demonstrated by the murder of Sennacherib, Esarhaddon made sure that he did not deviate even the slightest from the existing plan of the Aššur temple. To the dismay of some individuals connected to that temple, Esarhaddon did not undo the work of his father because that would have required him to alter the plan of the temple, the very thing he was advised not to do. Conflicted and anxious about these matters, Esarhaddon decided it best not to make any changes whatsoever to Aššur's temple.

\section{Duration and Scale of Esarhaddon's Work}

Esarhaddon appears to have started the project sometime in his first regnal year (680). If Aššurbanipal's inscriptions statement about him (Aššrurbanipal) completing the work on Aššur's temple is correct, then construction remained unfinished when Esarhaddon died in $669 .{ }^{59}$ How much work remained to be completed at the time of his death is uncertain. Based on the description of the interior decoration in Aššur-Babylon E, which was composed after IV-22-671 (Esarhaddon's tenth regnal year), it would appear that little work needed to be completed on the structure itself. Of course, one can never tell since the building reports of official inscriptions likely present the intentions of the king, rather than what he had actually achieved. Two door sockets attest to Esarhaddon still working on the temple during his tenth regnal year, a date that can be confirmed from the use of the title šar šarrāni Mușur Paturisi u Küsi "king of the kings of (Lower) Egypt, Upper Egypt, and Kush."

58. Leichty, Royal Inscriptions of Esarhaddon, 136 no. 60 1l. 29'b-33'a.

59. See n. 8 
How much of the temple Esarhaddon had completely rebuilt is not known and, thus, we can only speculate on the scale of the work. Because Sennacherib had a new multiroom complex (the "Ostanbau") added to the temple during the later part of his reign (ca. 688-681), it is not impossible that that part of Aššur's temple was still in good condition and did not need to be renovated. Of course, Esarhaddon may have renovated sections of it before decorating some of its gateways. It is tentatively suggested here that he rebuilt the structure of the entire temple, with the exception of his father's addition. To be more precise, Esarhaddon more or less rebuilt the Aššur temple as it was in the reign of Šalmaneser I (the pre-Sennacherib temple).

Because Esarhaddon claims to have decorated the "Gate of the Path of the Enlil-Stars," the "Royal Gate," and the "Kamsū-Igīgū Gate," it is certain that he did not dismantle his father's multiroom addition to the temple. This can be confirmed from the fact that his son and successor Aššrbanipal states that he had tall columns placed in the "Gate of the Abundance of the Land," which was one of the gates of Sennacherib's new complex. ${ }^{60}$ By not tearing down this section, Esarhaddon stayed true to his word and "did not alter the site where that temple stood."

\section{Conclusions}

Esarhaddon's statements about not changing the plan of the Aššur temple at Aššur and not deviating from the plan of Marduk's temple at Babylon stand out when one reads through the known Assyrian royal inscriptions. None of his predecessors make such claims. In fact, some kings proudly boast that they made changes or additions to temples. For example, Esarhaddon's father Sennacherib reports that he altered and expanded Aššur's temple, as well as changed the location of the akitu-house; and his son Ašsurbanipal claims to have enlarged the temple of the god Sîn (Ehulhul) at Harrān. The archaeological record provides evidence that Assyrian rulers prior to Esarhaddon did not appear to have had an issue with altering the plan or position of temples. For example, the plans of the Aššur, Ištar, and Sîn-Šamaš temples at Aššur were changed several times throughout their long histories. Of particular interest here, Šalmaneser I remodeled and expanded the Aššur temple that Šamšī-Adad I had constructed. The inclusion of ištêt ammatu ul ašẹt mišil ammatu ul utter, "I did not add a (single) cubit, nor subtract a half cubit" in Esarhaddon's Babylon Inscriptions and that of bìtu šuātu ašar maškanšu ul ušanni, "I did not alter the site where that temple stood" in his Aššur B inscription are probably rooted in events that took place during Sennacherib's reign. For Babylon, the aforementioned statement can be seen as a response to Sennacherib destroying Babylon and Esagil. For Aššur, the events behind Esarhaddon's reaction are not as obvious, but they may stem from the fact that his father Sennacherib altered the temple and cult, making them more like Esagil and its cult. These changes probably angered some of the members of the Aššur priesthood and, when Sennacherib was murdered in 681, those individuals likely regarded that king's death as divine retribution for his transgressions against the chief god of Assyria. ${ }^{61}$

Because Esarhaddon states in his Aššur B inscription that he did not deviate from the existing plan of the temple, the Assyrian king may have thought that his father had sinned against Aššur when the latter made significant modifications to that building and its cult. If this proposal proves correct, then one should view Esarhaddon's cautious attitude towards building temples precisely on their existing plans as perhaps a direct response to the death of his father, which he and/or his advisors may have seen as payback for destroying Marduk's temple at Babylon and altering Aššur's temple and cult at Aššur.

The idea that Sennacherib transgressed against Aššur may have originated from disgruntled members of the Aššur priesthood, who were not pleased by the changes that the Assyrian king was making to their temple and cult.

60. Borger, Beiträge zum Inschriftenwerk Assurbanipals, 138 Prism C i 19-20 // Prism T i 17-18 and 268 IIT 1. 29a.

61. Probably few people, if any, other than members of the Aššur priesthood believed that Sennacherib was murdered because he made changes to Aššur's temple, alterations that made it more like Esagil in Babylon. The alteration of the temple may have been one reason that was told to Esarhaddon when he was investigating the nature of his father's death, one that he appears to have taken seriously. 
They may not have minded those alterations had they not been to make Aššrur's temple more like Marduk's; that felt like adding insult to injury. When Sennacherib was murdered, their views on the regicide appear to have been passed on to the newly enthroned Esarhaddon. Sennacherib's successor was probably strongly advised against altering the plans of temples since that was a sin punishable by death, a lesson Sennacherib learned the hard way. The new king heeded that advice well, perhaps too well for the Aššur priesthood since Esarhaddon did not undo his father's changes and additions. It appears that by telling Esarhaddon that his father had sinned against the god Aššur by altering his temple their plan backfired to some extent. The Aššur priesthood was probably hoping that their new king would restore the temple back to the way it had been before Sennacherib changed it, but instead Esarhaddon kept it exactly the way it was, just as he was advised to do. By not changing the plan of the temple, Esarhaddon avoided offending Aššr the way his father was said to have done.

Unfortunately, given the lack of textual sources presently available, none of the conclusions made here can be confirmed and, therefore they must remain conjectural. However, it is hoped that the ideas presented in this paper will stimulate further thought and discussion on Esarhaddon's reaction to his father's death and his cautious attitude towards building temples precisely on their existing plans.

\section{Appendix: Previous Builders Mentioned in Late Assyrian Royal Inscriptions ${ }^{62}$}

Extant royal inscriptions provide evidence for twelve (or possibly thirteen or fourteen) Assyrian rulers between Šalmaneser I and Esarhaddon having worked on the Aššur temple. The certain rulers are Tukulti-Ninurta I, Aššur-rēšì-iši I, Aššur-dān II, Tukultī-Ninurta II, Aššurnasirpal II, Šalmaneser III, Adad-nārārī III, Aššur-dān III, Tiglath-pileser III, Sargon II, and Sennacherib; Erība-Adad II and Šalmaneser II may have also sponsored construction on the temple. ${ }^{63}$ None of the aforementioned Assyrian kings are named as previous builders in Esarhaddon’s Aššur A and Aššur B inscriptions. At first glance, this may seem a little unusual, but in fact the information included in Aššur A and Aššur B is more or less typical for a late Neo-Assyrian royal inscription (744-ca. 609). To demonstrate this, let us present the available textual evidence and briefly discuss who is mentioned as a previous builder.

From the extant textual evidence, building reports in inscriptions written 744-ca. 609 are very selective when it comes to mentioning previous builders. Usually only one ruler is named; rarely is more than one king cited. Aššur $\mathrm{A}$ is one of the four known late Assyrian royal inscriptions that mentions more than one previous builder. It is also one of three texts from this period to include a span of time between the rebuildings; Aššur B is one of the other two ${ }^{64}$ Aššur A and Aššur B are unusual in this regard since late Neo-Assyrian official inscriptions generally just name the previous builder without providing any chronological information. In the inscriptions of Sargon II, Sennacherib, and Esarhaddon, only distant rulers are cited as previous builders. These kings never refer to their father or grandfather in connection with their building activities. However, the inscriptions of Aššurbanipal and Sîn-šarra-iškun mention either one of their immediate predecessors or one (or more) early ruler(s). For example, Aššrurbanipal states that Sargon II had worked on the akitu-temple at Nineveh. In cases when both the king' father and grandfather are known to have worked on the same structure, only one of them is cited. For example, some inscriptions of Aššrbanipal record that his grandfather Sennacherib had worked on the armory at Nineveh, but

62. The information provided here is a general overview of a more detailed study upon which I am working.

63. For the evidence, see H. Galter, "Geschichte als Bauwerk: Der Aššurtempel und das assyrische Geschichtsbewusstein," in From The Upper Sea to the Lower Sea: Studies on the History of Assyria and Babylonia in Honour of A. K. Grayson, ed. G. Frame, PIHANS 101 (Leiden: Nederlands Institut voor het Nabije Oosten, 2004), 126-27.

64. A Sargon II inscription recording work on the Nabû temple at Nineveh (H. C. Rawlinson and G. Smith, The Cuneiform Inscriptions of Western Asia, vol. 3: A Selection from the Miscellaneous Inscriptions of Assyria [London: R. E. Bowler, 1870], pl. 3 no. 12 11. 4-5) states that seventy-five years had passed between Adad-nārārī III's rebuilding and his own work. 
Table 1. Rulers named in building reports of late Neo-Assyrian kings.*

\begin{tabular}{|c|c|c|c|c|}
\hline City & Structure & Recent Ruler & Earlier Ruler(s) & Source \\
\hline \multicolumn{5}{|l|}{ Sargon II } \\
\hline Kalhu & Northwest Palace & - & Aššurnasirpal (II) & $\begin{array}{l}\text { H. Winckler, Die Keilschrifttext Sargons nach den } \\
\text { papierabklatschen und Originalen (Leipzig: Eduard } \\
\text { Pfeifer, 1889), 1:170-71 and 2:pl. } 48 \text { 1. } 13\end{array}$ \\
\hline Nineveh & Nabû temple & - & Adad-nārārī (III) & $\begin{array}{l}\text { H. C. Rawlinson and G. Smith, The Cuneiform } \\
\text { Inscriptions of Western Asia, vol. 3: A Selection } \\
\text { from the Miscellaneous Inscriptions of Assyria } \\
\text { (London: R. E. Bowler, 1870), pl. } 3 \text { no. } 12 \text { 1l. } 4-5\end{array}$ \\
\hline Tìl-Barsip & Adad temple & - & Aššurnasirpal (II) & $\begin{array}{l}\text { A. Fuchs, Die Annalen des Jahres } 711 \text { v. Chr. nach } \\
\text { Prismenfragmenten aus Ninive und Assur, SAAS } \\
8 \text { (Helsinki: Vammalan Kirjapaino Oy, 1998), } 511 . \\
7^{\prime}-8^{\prime}\end{array}$ \\
\hline Uruk & Ištar temple & - & Shulgi & Frame, Rulers of Babylonia, no. B.6.22.3 ll. 18-20 \\
\hline \multicolumn{5}{|c|}{ Sennacherib } \\
\hline Aššur & Old Palace & - & $\begin{array}{l}\text { Tiglath-pileser (I), } \\
\text { Aššurnasirpal (II) }\end{array}$ & $\begin{array}{l}\text { Grayson and Novotny, Royal Inscriptions of } \\
\text { Sennacherib, 2:no. } 164 \text { ll. 1-6 }\end{array}$ \\
\hline Nineveh & $\begin{array}{l}\text { Lady of Nineveh } \\
\text { temple }\end{array}$ & - & Aššurnasirpal (II) & $\begin{array}{l}\text { Grayson and Novotny, Royal Inscriptions of } \\
\text { Sennacherib, 1:no. } 36 \text { rev. } 3^{\prime}-7^{\prime}\end{array}$ \\
\hline Nineveh & Sîn-Šamaš temple & - & Aššurnasirpal (II) & $\begin{array}{l}\text { Grayson and Novotny, Royal Inscriptions of } \\
\text { Sennacherib, 1:no. } 36 \text { rev. } 3^{\prime}-7^{\prime}\end{array}$ \\
\hline Nineveh & $\begin{array}{l}\text { temple (name not } \\
\text { preserved) }\end{array}$ & - & Aššurnasirpal (II) & $\begin{array}{l}\text { Grayson and Novotny, Royal Inscriptions of } \\
\text { Sennacherib, 1:no. } 36 \text { rev. } 3^{\prime}-7^{\prime}\end{array}$ \\
\hline Tarbișu & Nergal temple & - & Šalmaneser (III) & $\begin{array}{l}\text { Grayson and Novotny, Royal Inscriptions of } \\
\text { Sennacherib, 2:no. } 2131.62\end{array}$ \\
\hline \multicolumn{5}{|c|}{ Esarhaddon } \\
\hline Aššur & Aššur temple & - & Šalmaneser (I) & $\begin{array}{l}\text { Leichty, Royal Inscriptions of Esarhaddon, no. } 58 \text { iii } \\
8-16 \text {, no. } 59 \text { i 19-22, no. } 60 \text { ll. } 17^{\prime} \text { b-19'a }\end{array}$ \\
\hline Aššur & Aššur temple & - & $\begin{array}{l}\text { Ušpia, } \\
\text { Erišum (I), } \\
\text { Šamši-Adad (I), } \\
\text { Šalmaneser (I) }\end{array}$ & $\begin{array}{l}\text { Leichty, Royal Inscriptions of Esarhaddon, no. } 57 \\
\text { iii 16-34 }\end{array}$ \\
\hline Kalhu & Fort Šalmaneser & - & Šalmaneser (III) & $\begin{array}{l}\text { Leichty, Royal Inscriptions of Esarhaddon, no. } 7711 . \\
42-43 \text {, no. } 81 \text { ll. } 3 b-5 a \text {, and no. } 82 \text { ll. } 2 \text { b-3a }\end{array}$ \\
\hline Kalhu & Tebilti canal & - & Aššurnasirpal (II) & $\begin{array}{l}\text { Leichty, Royal Inscriptions of Esarhaddon, no. } 87 \\
\text { ll. 6-7 }\end{array}$ \\
\hline Uruk & Nanāya shrine & - & $\begin{array}{l}\text { Nazi-Maruttaš, } \\
\text { Erība-Marduk }\end{array}$ & $\begin{array}{l}\text { Leichty, Royal Inscriptions of Esarhaddon, no. } 137 \\
\text { ll. 11-14 }\end{array}$ \\
\hline \multicolumn{5}{|c|}{ Aššurbanipal } \\
\hline Kalhu & Nabû temple & - & Adad-nārārī (III) & $\begin{array}{l}\text { Borger, Beiträge zum Inschriftenwerk } \\
\text { Assurbanipals, } 164 \text { Prism CND x 88-90 }\end{array}$ \\
\hline Harrān & Sîn temple & - & Šalmaneser (III) & $\begin{array}{l}\text { Borger, Beiträge zum Inschriftenwerk } \\
\text { Assurbanipals, } 142 \text { Prism C i 78b-79 and Prism T } \\
\text { ii } 39-41 \text {, and } 186 \text { LET rev. } 37-38\end{array}$ \\
\hline Nineveh & akìtu-temple & Sargon (II) & - & $\begin{array}{l}\text { Borger, Beiträge zum Inschriftenwerk } \\
\text { Assurbanipals, } 169 \text { v } 38 \mathrm{a}-42\end{array}$ \\
\hline
\end{tabular}

\footnotetext{
* The extant inscriptions of Tiglath-pileser III, Šalmaneser V, and Aššur-etel-ilāni do not mention any previous rulers in their building reports so these three rulers are not included in table 1. Because there are no known official inscriptions of Sîn-šumu-lěšir and Aššur-uballit II, those kings are also not included in the chart. The brief comments after table 1 also do not deal with these aforementioned Assyrian kings.
} 


\begin{tabular}{|c|c|c|c|c|}
\hline City & Structure & Recent Ruler & Earlier Ruler(s) & Source \\
\hline Nineveh & armory & Sennacherib & - & $\begin{array}{l}\text { Borger, Beiträge zum Inschriftenwerk } \\
\text { Assurbanipals, } 117 \text { Prism B viii 64-67 }\end{array}$ \\
\hline Nineveh & armory & Esarhaddon & - & $\begin{array}{l}\text { Borger, Beiträge zum Inschriftenwerk } \\
\text { Assurbanipals, } 163 \text { Prism C x 88-90 (name } \\
\text { restored from p. } 164 \times 111 \text { and 118) }\end{array}$ \\
\hline Nineveh & citadel wall & Sennacherib & - & $\begin{array}{l}\text { Borger, Beiträge zum Inschriftenwerk } \\
\text { Assurbanipals, } 118 \text { Prism D viii } 64-68 \text { and } 183 \\
\text { Prism E Stück } 18 \text { ll. } 4-6\end{array}$ \\
\hline Nineveh & Ištar temple & - & Aššurnasirpal (II) & $\begin{array}{l}\text { Borger, Beiträge zum Inschriftenwerk } \\
\text { Assurbanipals, } 288 \text { IIT 1. } 166\end{array}$ \\
\hline Nineveh & North Palace & Sennacherib & - & $\begin{array}{l}\text { Borger, Beiträge zum Inschriftenwerk } \\
\text { Assurbanipals, } 73 \text { Prism F vi } 22-27 \text { a and Prism A } \\
\text { x 51-56 }\end{array}$ \\
\hline Nineveh & Sîn-Šamaš temple & Esarhaddon & - & $\begin{array}{l}\text { Borger, Beiträge zum Inschriftenwerk } \\
\text { Assurbanipals, } 144 \text { Prism T iii 18-22 and Prism } \\
\text { Tvar2 i' 9-14 }\end{array}$ \\
\hline \multicolumn{5}{|c|}{ Sîn-šarra-iškun } \\
\hline Aššur & Nabû temple & - & $\begin{array}{l}\text { Šalmaneser (I), } \\
\text { Aššur-rēšī-iši (I), } \\
\text { Adad-nārārī (III) }\end{array}$ & $\begin{array}{l}\text { W. Meinhold, Ištar in Aššur: Untersuchung eines } \\
\text { Lokalkultes von ca. } 2500 \text { bis } 614 \text { v. Chr., AOAT } \\
367 \text { (Münster: Ugarit-Verlag, 2009), } 453 \text { no. } 1111 . \\
\text { 41b-45a }\end{array}$ \\
\hline Kalhu & Nabû temple & - & Adad-nārārī (III) & $\begin{array}{l}\text { J. Novotny and G. Van Buylaere, "Sîn-šarru-iškun } \\
\text { and Ezida in Calah," in Homeland and Exile: } \\
\text { Biblical and Ancient Near Eastern Studies in } \\
\text { Honour of Bustenay Oded, ed. G. Galil, M. Geller, } \\
\text { and A. Millard, VTSuppl. } 130 \text { (Leiden: Brill, 2009), } \\
228 \text { 1. } 31\end{array}$ \\
\hline Nineveh & Southwest Palace & Sennacherib & - & $\begin{array}{l}\text { L. W. King, Cuneiform Texts from Babylonian } \\
\text { Tablets in the British Museum } 34 \text { (London: British } \\
\text { Museum, 1914), pl. } 3 \text { Ki 1904-10-9, 362+ ll. } \\
11^{\prime}-12^{\prime}\end{array}$ \\
\hline
\end{tabular}

other texts state that his father Esarhaddon had undertaken construction on that same armory. ${ }^{65}$ In cases when both immediate predecessors and well known earlier rulers sponsored construction on a particular building, the earlier ruler is always given preference. For example, both Aššurbanipal and Sîn-šarra-iškun refer to Adad-nārārī III as the previous builder of the Nabû temple at Kalhu. In the former case, Esarhaddon, Sennacherib, and possibly Sargon II are not referred to, and, in the latter case, Aššur-etel-ilāni and Aššurbanipal are not listed as previous builders. Given the extant textual evidence, the lists of previous rulers in Aššur A and Aššur B appears to more or less follow the model of Esarhaddon's immediate predecessors an, therefore Esarhaddon was not expected to cite Sargon II or Sennacherib as previous builders of the Aššur temple since at least one well known earlier Assyrian king had worked on it: Šalmaneser I.

65. This may have been because Aššurbanipal's Prism B (Borger, Beiträge zum Inschriftenwerk Assurbanipals, 117 Prism B viii 64-67) was to be deposited in the walls of the section of the armory constructed by Sennacherib and because his Prism C (ibid., 163 Prism C x 88-90) was to be placed in the wing built by Esarhaddon. 
This brings us to which earlier kings were mentioned. ${ }^{66}$ Aššurnasirpal II, Šalmaneser III, and Adad-nārārī III are the only early Neo-Assyrian kings mentioned as previous builders. Based on the number of attestations for each of them, it appears that late Neo-Assyrian royal scribes were selective when mentioning early Neo-Assyrian kings in a building report. Thus, it seems unlikely that the following kings would be named as a previous builder by Sargon II and his successors in their official inscriptions: Aššur-dān II, Tukultī-Ninurta II, Adad-nārārī II, Šamšī-Adad V, Šalmaneser IV, Aššur-dān III, Aššur-nārārī V, Tiglath-pileser III, and Šalmaneser V. Šalmaneser I, Aššur-rēšì-iši I, and Tiglath-pileser I are the three known Middle Assyrian kings included in late Neo-Assyrian building reports. There is not sufficient evidence at this time to be able to determine which other Middle Assyrian kings would have also been worthy of being referred to as a previous builder. Adad-nārārī I and Tukultī-Ninurta I may have made the cut. Ušpia, Erišum I, and Šamšì-Adad I are the only three Old Assyrian kings cited as previous builders. Their mention in Esarhaddon's Aššur A inscription is probably due to the fact that Esarhaddon's scribes were copying that information directly from the texts of Šalmaneser I that had been discovered in the Aššur temple. Moreover, the inclusion of these rulers linked Esarhaddon back to the founding of the temple, making him the fifth ruler-the first after Šalmaneser I-to have undertaken construction on Aššur's holy residence. This list may have also underscored the message that Esarhaddon was rebuilding the temple exactly as it had been previously, unlike his father Sennacherib who had changed it. ${ }^{67}$

66. Foreign rulers are seldom mentioned. See Frame, Rulers of Babylonia, no. B.6.22.3 11. 18-20 and Leichty, Royal Inscriptions of Esarhaddon, no. 137 11. 11-14. In the building reports of the inscriptions of Esarhaddon and Aššurbanipal a Babylonian ruler is usually referred to as "a previous king" (šarru maḩû or šar pāni mahrīya). See, for example, Borger, Beiträge zum Inschriftenwerk Assurbanipals, 85 Nergal-Laș Inscription 1. 78; and Leichty, Royal Inscriptions of Esarhaddon, 262 no. 128 1. 15.

67. Adding the name of Aššurnasirpal II, Šalmaneser III, or Adad-nārārī III after Šalmaneser I in the list of previous builders would have lessened the impact of Esarhaddon's message. 